

\title{
Volcanic Hazards of the Idaho National Engineering Laboratory and Adjacent Areas
}

\author{
William R. Hackett \\ WRH Assoclates \\ 2880 E. Naniloa Circle \\ Salt Lake City, UT 84117-5523 \\ Richard P. Smith \\ Lockheed Idaho Technologies Company \\ P.O. Box 1625, Mall Stop 2107 \\ Idaho Falls, ID 83415
}

December 1994

DISTRIBUTION OF THIS DOCUMENT IS UNLIMTED
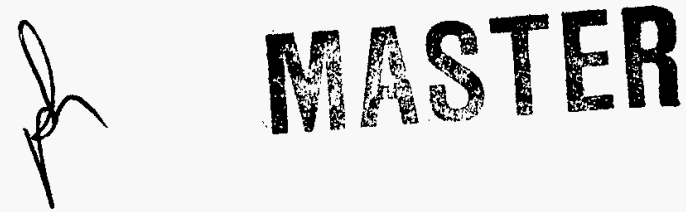

Idaho National Engineering Laboratory Lockheed Idaho Technologies Company Idaho Falls, Idaho $\mathbf{8 3 4 1 5}$

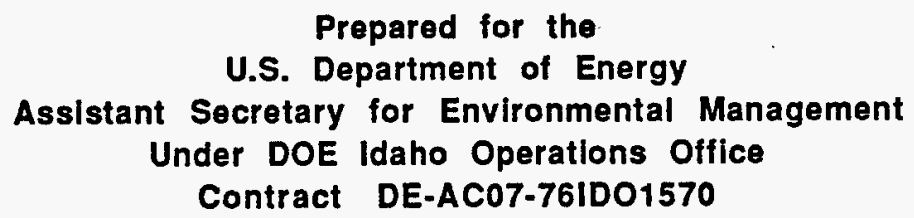





\section{DISCLAIMER}

This report was prepared as an account of work sponsored by an agency of the United States Government. Neither the United States Government nor any agency thereof, nor any of their employees, makes any warranty, express or implied, or assumes any legal liability or responsibility for the accuracy, completeness, or usefulness of any information, apparatus, product, or process disclosed, or represents that its use would not infringe privately owned rights. Reference berein to any specific commercial product, process, or service by trade name, trademark, manufacturer, or otherwise does not necessarily constitute or imply its endorsement, recommendation, or favoring by the United States Government or any agency thereof. The views and opinions of authors expressed herein do not necessarily state or reflect those of the United States Government or.any agency thereof. 


\section{EXECUTIVE SUMMARY}

Potential volcanic hazards are assessed, and hazard zone maps are developed for the Idaho National Engineering Laboratory (INEL) and adjacent areas. The basis of the hazards assessment and mapping is the past volcanic history of the INEL region, and the apparent similarity of INEL volcanism with equivalent, well-studied phenomena in other regions of active volcanism, particularly Hawaii and Iceland. The most significant hazards to INEL facilities are associated with basaltic volcanism, chiefly lava flows, which move slowly and mainly threaten property by inundation or burning. Related hazards are volcanic gases and tephra, and ground disturbance associated with the ascent of magma under the volcanic zones. Several volcanic zones are identified in the INEL area. These zones contain most of the volcanic vents and fissures of the region and are inferred to be the most probable sites of future INEL volcanism.

Volcanic-recurrence estimates are given for each of the volcanic zones based on geochronology of the lavas, together with the results of field and petrographic investigations concerning the cogenetic relationships of INEL volcanic deposits and associated magma intrusion. Annual probabilities of basaltic volcanism within the INEL volcanic zones range from $6.2 \times 10^{-5}$ per year (average 16,000-year interval between eruptions) for the axial volcanic zone near the southern INEL boundary and the Arco volcanic-rift zone near the western INEL boundary, to $1 \mathrm{x}$ $10^{-5}$ per year (average 100,000-year interval between eruptions) for the Howe-East Butte volcanic rift zone, a geologically old and poorly defined feature of the central portion of INEL.

Three volcanic hazard zone maps are developed for the INEL area: lava flow hazard zones, a tephra (volcanic ash) and gas hazard zone, and a ground-deformation hazard zone (faulting and fissuring associated with magma intrusion). The maps are useful in land-use planning, site selection, and safety analysis. The potential effects of ground deformation, tephra, and gases are largely restricted to near-vent areas within the volcanic zones. However, lava flows may travel far from their sources and the statistics of INEL lava flow lengths and areas are used to define two lava flow hazard zones. These two zones cover a larger area than zones for tephra, gases, and ground deformation. The zone of high lava flow hazard is within $8 \mathrm{~km}$ of volcanic vents younger than 400,000 years. The general probability of lava inundation, tephra fall, gas emission, or ground deformation at a random site within the high-hazard zones will vary with location, but is estimated to range from about $3 \times 10^{-5}$ per year to $4 \times 10^{-6}$ per year. These values are $2-3$ orders of magnitude lower than those for the high-hazard areas associated with active volcanic zones in Iceland and Hawaii. The annual probabilities (recurrence estimates) for INEL volcanic zones express the probabilities of eruption within each of the volcanic zones, but not the probability of impact upon individual INEL facilities or locations. Probabilistic-risk assessments for specific INEL facilities would use the recurrence data developed here, but risk analysis would also consider additional factors including distance and direction for volcanic sources, the influence of local topography, the consequences of volcanic disruption, and potential mitigation measures. 


\section{CONTENTS}

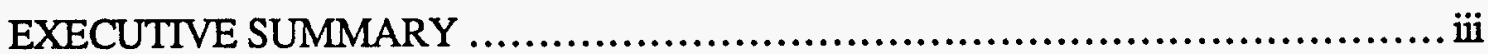

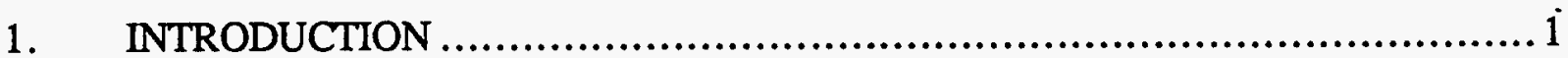

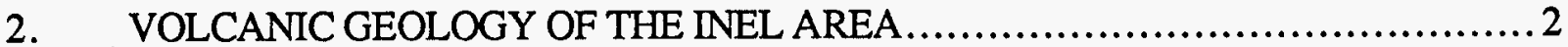

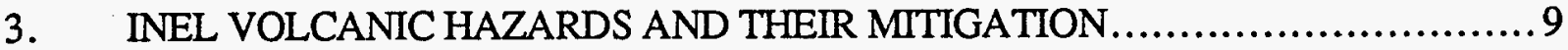

4. INEL VOLCANIC RECURRENCE............................................. 13

4.1 Methods of Estimating Volcanic Recurrence................................ 13

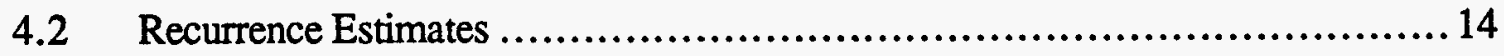

5. LENGTHS AND AREAS OF INEL BASALT LAVA FLOWS ..................... 16

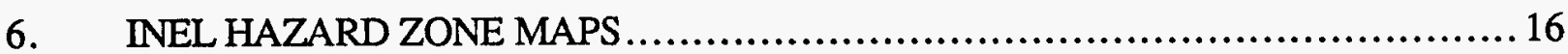

6.1 Lava Flow Hazard .Zones................................................... 21

6.2 General Probabilities of Eruption and Lava Flow Inundation......................25

6.3 Tephra Fall and Volcanic Gases ........................................... 26

6.4 Ground Deformation Associated with Dike Intrusion.............................. 26

6.5 Comparison of INEL and Hawaiian Hazard Zones ......................... 27

7. CONCLUSIONS ............................................................ 27

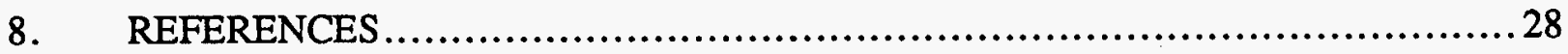

\section{FIGURES}

1. Generalized geologic map of the INEL area........................................5

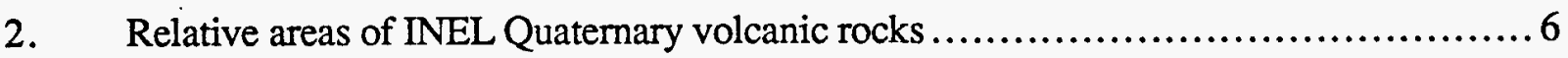

3. Number of volcanic vents per $140 \mathrm{~km} 2$ in the eastern Snake River Plain ...............7

4. Map showing major volcanic and tectonic elements of the INEL area $\ldots \ldots \ldots \ldots \ldots \ldots \ldots 8$

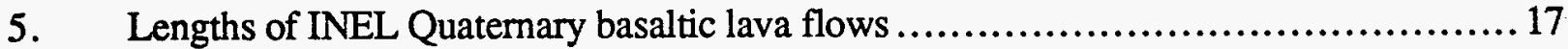

6. Areas of INEL Quaternary basaltic lava flows.................................... 18

7. Map showing volcanic vents and volcanic recurrence intervals for volcanic zones

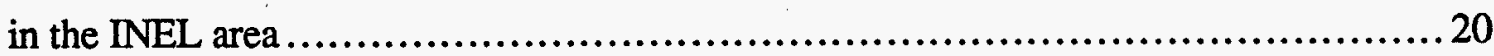

8. Lava flow hazard zone map of the INEL area........................................ 22

9. Tephra (ash) and gas hazard zone map of the INEL area..........................23

10. Ground deformation hazard zone map for the INEL area $\ldots \ldots \ldots \ldots \ldots \ldots \ldots \ldots \ldots \ldots \ldots . . .24$

\section{TABLES}

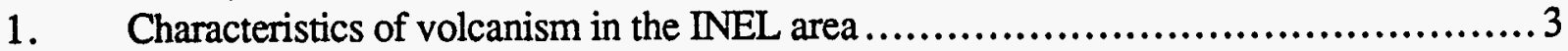

2. Hazards associated with basaltic volcanism on the Eastern Snake River Plain ........... 10 
3. Estimated volcanic-recurrence intervals and corresponding annual eruption probabilities (in parentheses) for volcanic zones and boreholes of the INEL area.......... 12

4. Statistical summary of lava flow lengths and areas of INEL Quaternary basalts .......... 19 


\section{INTRODUCTION}

This report discusses the characteristics, location, frequency and extent of potentially hazardous volcanic phenomena in the area of the Idaho National Engineering Laboratory (INEL). The distribution of significant volcanic hazards are shown on hazard zone maps of the INEL and adjacent areas. The INEL is located near the northern margin of the Eastern Snake River Plain (ESRP), a region that underwent explosive silicic volcanism during the early stages of its development, between about 7 million and 4.3 million years ago. Later volcanism of the past 4 million years has largely involved the mild effusion of basaltic lava flows. Eruptions occurred as recently as about 2,100 years ago along the Great Rift about $30 \mathrm{~km}$ west of the INEL, and the youngest lava flows near the INEL are about 5,400 years old.

Although sometimes the two terms are used interchangeably, there is a difference between 'hazard' and 'risk' (Fournier D'Albe, 1986; Reiter, 1990). 'Volcanic hazards' describe the potential for dangerous natural phenomena associated with volcanism. Direct hazards result from eruptions of magma onto the land surface (e.g., lava flows) or into the atmosphere (e.g., volcanic ash or gases). Indirect hazards result from events that accompany such eruptions, are the secondary effects of eruptions, or result from underground movement of magma that does not erupt (e.g., dike-induced tensile fissuring and ground inflation). Future INEL volcanism could produce hazard in near-vent areas, and lava flows or land-surface deformation associated with magma intrusion could affect areas many kilometers from the sites of volcanic eruption.

'Volcanic risk,' in contrast, describes the likelihood of losses to people or property, and can be thought of as the product of the hazard multiplied by the consequences. Probabilistic volcanic hazards assessment (the probabilities of occurrence of specific volcanic phenomena within defined areas) is the subject of this report. Volcanic risk (the probabilities of specific impacts to specific facilities; i.e., the consequences of volcanic phenomena) is not addressed here, but the quantitative hazards information contained in this report provides the foundation for volcanic-risk assessments of critical INEL facilities.

General references on volcanic hazards (Blong, 1984; Latter, 1989) and lava flows (Fink, 1990; Kilburn and Luongo, 1994) provide fundamental approaches to volcanic hazard assessment, and detailed accounts of the geologic record of the ESRP and the INEL area provide the specific data for the assessment. Kuntz et al. (1992) and Kuntz (1992) discuss the regional geology of the ESRP, and recent summaries of INEL geology include Hackett and Smith (1992) and Kuntz et al. (1994). Interpretation of the local geology is the basis for estimating the frequency (recurrence) and style of future INEL volcanism.

Previous volcanic-hazard assessments of the INEL area include Kuntz (1978), Kuntz and Dalrymple (1979) and the Volcanism Working Group (1990). Although these assessments form a foundation upon which to build, they have either been outdated by subsequent information, are insufficiently quantitative, or address specific INEL localities. In contrast, this report considers the entire area of the INEL and its surrounding region. Quantitative volcanic-recurrence estimates are given for INEL volcanic zones. The statistics of lava flow lengths and areas in the INEL region are derived and used to construct maps of lava flow, tephra and gas, and ground deformation hazard zones. 
Observations of active volcanism in analogous regions such as Hawaii (Decker et al., 1987) and Iceland (Sigurdsson, 1980; Gudmundsson, 1987) are also useful in forecasting and mitigating the effects of future INEL eruptions. This report approaches the problem of quantitative volcanic-hazards assessment in a fashion similar to that of Mullineaux et al. (1987) and Wright et al. (1992) for the Hawaiian Islands. The conceptual framework of this report is also influenced by a preliminary, qualitative assessment for Iceland (Imsland, 1989). However, all volcanic provinces are unique, and the foundation of this report is necessarily the published literature of ESRP and INEL volcanic geology.

\section{VOLCANIC GEOLOGY OF THE INEL AREA}

The general characteristics of volcanism in the INEL area are summarized in Table 1. Early volcanism in the INEL region is best described within the context of the Yellowstone mantle plume, a source of heat and magma that passed beneath southern Idaho during the past 15 million years, leaving the 600-km-long Snake River Plain in its wake (Pierce and Morgan, 1992; Smith and Braile, 1993). As the North American continent drifted westward, the mantle plume left a trail of large silicic eruptive centers becoming progressively younger to the northeast, and culminating in the Quaternary Yellowstone Plateau volcanic field. The main products of these early explosive eruptions were widespread and voluminous silicic ash-flow tuffs. Beneath the INEL area, silicic volcanism produced large calderas and voluminous ash-flow tuffs between about 6.5 and 4.3 million years ago (Morgan et al., 1984; Pierce and Morgan, 1992). The Yellowstone plume is considered to underlie northwestern Wyoming, and is marked by geophysically anomalous crust and upper mantle (Smith and Christiansen, 1980), regional uplift of the Yellowstone Plateau, voluminous silicic volcanism of the Yellowstone Plateau volcanic field during the past 2.1 million years (Hildreth et al., 1991), and by the present-day high heat flow and geothermal features associated with the Yellowstone caldera.

The plume hypothesis and the migration of early silicic volcanism on the ESRP have several implications for INEL volcanic-hazards assessment. These implications include:

(1) The available evidence from the Quaternary Yellowstone Plateau volcanic field suggests that the recurrence of major, caldera-forming silicic eruptions is about 500,000 years (annual probability less than $2 \times 10^{-6}$ ).

(2) Explosive silicic volcanism associated with plume passage beneath the INEL area took place 6.5 to 4.3 million years ago. Recurrence intervals during that period were approximately 700,000 years, and about six recurrence intervals have passed since the latest caldera-forming eruptions occurred in the INEL area.

(3) During the past 4.3 million years, the centers of explosive volcanism have migrated to the Yellowstone region, several hundred kilometers northeast of the INEL.

Together, these factors imply that the INEL is unlikely to be significantly affected by future, caldera-forming volcanism (Volcanism Working Group, 1990), and the subject is, therefore, not further analyzed in this report. 


\begin{tabular}{|c|c|c|c|c|}
\hline & $\begin{array}{l}\text { CALDERA } \\
\text { FORMATION } \\
\end{array}$ & $\begin{array}{l}\text { RIFT-ZONE } \\
\text { VOLCANISM } \\
\end{array}$ & $\begin{array}{l}\text { AXIAL-ZONE } \\
\text { VOLCANISM } \\
\end{array}$ & $\begin{array}{l}\text { AREAS BETWEEN } \\
\text { VOLCANIC ZONES }\end{array}$ \\
\hline MAGMA TYPES & $\begin{array}{l}\text { rhyolite } \\
\text { (viscous and gas-rich) }\end{array}$ & $\begin{array}{l}\text { basalt } \\
\text { (fluid and gas-poor) }\end{array}$ & $\begin{array}{l}\text { basalt and } \\
\text { subordinate rhyolite }\end{array}$ & $\begin{array}{l}\text { basalt } \\
\text { (and minor rhyolite?) }\end{array}$ \\
\hline $\begin{array}{l}\text { VOLCANIC STYLE } \\
\text { AND PRODUCTS }\end{array}$ & $\begin{array}{l}\text { highly explosive; } \\
\text { voluminous pumice and } \\
\text { fine ash blankets entire } \\
\text { regions }\end{array}$ & $\begin{array}{l}\text { mild \& effusive; erupt } \\
\text { mainly lava flows from } \\
\text { fissures, low shield } \\
\text { volcanoes and small } \\
\text { tephra cones }\end{array}$ & $\begin{array}{l}\text { as per rift zones, but } \\
\text { also local rhyolite domes } \\
\text { \& intrusions (Big } \\
\text { Southern, Middle, East } \\
\text { Buttes) with local } \\
\text { explosive phenomena }\end{array}$ & $\begin{array}{l}\text { as per volcanic rift zones } \\
\text { and axial volcanic zone }\end{array}$ \\
\hline STRATIGRAPHY & $\begin{array}{l}\text { calderas filled with up to } \\
\text { several km of welded, } \\
\text { silicic ash-flow tuffs, lava } \\
\text { flows and volcaniclastic } \\
\text { sediment } \\
\text { [Heise Volcanics] }\end{array}$ & $\begin{array}{l}\text { piles of } 1-\text { to } 30 \text {-m-thick } \\
\text { basalt lava flows \& minor } \\
\text { interbedded sediment; } \\
\text { total lava thickness } \\
\text { up to } 1 \mathrm{~km} \text { in INEL area } \\
\text { [Snake River Group] }\end{array}$ & $\begin{array}{l}\text { basaltic lava flows and } \\
\text { dispersed small tephra } \\
\text { cones; isolated rhyolite } \\
\text { domes and intrusions } \\
\text { [Snake River Group] }\end{array}$ & $\begin{array}{l}\text { fine clastic sediment of } \\
\text { fluvial, lacustrine and } \\
\text { eolian origin; fewer lava } \\
\text { flows than near VRZs } \\
\text { [Snake River Group] }\end{array}$ \\
\hline $\begin{array}{l}\text { TECTONICS AND } \\
\text { PHYSICAL } \\
\text { CONFIGURATION }\end{array}$ & $\begin{array}{l}\text { collapse: broad, oval } \\
\text { depressions, } 10 \mathrm{~s} \text { to } \\
100 \mathrm{~km} \text { wide and } 1-2 \mathrm{~km} \\
\text { deep, ringed by inward- } \\
\text { dipping fractures }\end{array}$ & $\begin{array}{l}\text { extensional: NW- } \\
\text { trending belts of open } \\
\text { fissures, monoclines, } \\
\text { small normal faults and } \\
\text { basaltic vents }\end{array}$ & $\begin{array}{l}\text { extensional, but magma- } \\
\text { induced fissures or } \\
\text { faults are rare; a diffuse, } \\
\text { NE-trending, volcanic } \\
\text { highland along the } \\
\text { ESRP axis }\end{array}$ & $\begin{array}{l}\text { subsidence(?): broad, } \\
\text { low topographic basins } \\
\text { between extensional } \\
\text { and constructional } \\
\text { volcanic highlands; } \\
\text { seldom disturbed by } \\
\text { magma intrusion } \\
\end{array}$ \\
\hline $\begin{array}{l}\text { GEOLOGIC AGE } \\
\text { IN INEL AREA : }\end{array}$ & $\begin{array}{l}6.5 \mathrm{Ma} \text { to } 4.3 \text { million yrs } \\
\text { in INEL area, now } \\
\text { covered by younger } \\
\text { basaltic lava. } \\
{[2.1 \text { to } 0.6 \text { million yrs on }} \\
\text { Yellowstone Plateau] }\end{array}$ & $\begin{array}{l}\text { Surficial INEL basalts: } \\
1.2 \text { to } 0.05 \text { million yrs; } \\
\text { most are } 0.7 \text { to } 0.1 \\
\text { million yrs. Inception of } \\
\text { major basaltic volcanism } \\
\text { was ca. } 4 \text { million yrs ago. }\end{array}$ & $\begin{array}{l}\text { Basalt: }>1 \text { million yrs } \\
\text { (Middle Butte), to } 5,400 \\
\text { yrs (Hells Half Acre). } \\
\text { Rhyolite: }>1 \text { million yrs } \\
\text { (near East Butte) to } \\
300,000 \text { yrs (Big } \\
\text { Southern Butte) } \\
\end{array}$ & as per VRZs \\
\hline $\begin{array}{l}\text { QUATERNARY } \\
\text { ERUPTION } \\
\text { FREQUENCY }\end{array}$ & $\begin{array}{l}\text { zero in INEL area; } \\
\text { Quaternary calderas } \\
\text { closest to INEL occur on } \\
\text { Yellowstone Plateau }\end{array}$ & $\begin{array}{l}\text { low; one eruption per } \\
35,000 \text { to } 125,000 \text { yrs } \\
\text { (see Table } 3 \text { ) }\end{array}$ & $\begin{array}{l}\text { low: one basaltic } \\
\text { eruption per } 35,000 \text { yrs } \\
\text { (see Table } 3 \text { ); } \\
\text { one rhyolitic intrusion or } \\
\text { dome every } 200,000 \text { yrs } \\
\text { or longer }\end{array}$ & $\begin{array}{l}\text { very low; by definition } \\
\text { less frequent than within } \\
\text { rift zones; one eruption } \\
\text { per } 125,000 \text { yrs or } \\
\text { longer }\end{array}$ \\
\hline
\end{tabular}

Table 1. Characteristics of volcanism in the INEL area. See Figure 4 for map distribution of volcanic zones and related features. 
During approximately the past 4.5 million years, the ESRP has been repeatedly inundated by basaltic lava flows, and these deposits now largely cover the earlier calderas, silicic tuffs and lava flows. Much of the $2,315 \mathrm{~km}^{2}$ tract of the INEL is underlain by basaltic lava flows, either exposed on the present land surface or beneath a cover of surficial sediment (Scott, 1982; Kuntz et al., 1994). Deep boreholes on the INEL have intersected up to $1 \mathrm{~km}$ of late Tertiary and Quaternary basalt lava flows and interbedded sedimentary deposits, overlying Neogene silicic tuffs (Hackett and Smith, 1992). Unlike the early silicic volcanism, no systematic, eastward migration of basaltic volcanism is apparent on the Snaki River Plain, and Holocene lavas (younger than 15,000 years) occur across the province. No eruptions have occurred on the ESRP during recorded history, but basaltic lava flows of the Hell's Half Acre lava field erupted near the southern INEL boundary as recently as 5,400 years ago, and eruptions occurred as recently as 2,100 years ago along the Great Rift, $30 \mathrm{~km}$ southwest of the INEL (Kuntz et al., 1986).

Isolated volcanic domes of Quaternary rhyolite also occur within the predominant basalts of the ESRP. The domes were emplaced between about 1.4 and 0.3 million years ago along the northeast-trending, central topographic axis of the ESRP (Kuntz et al., 1994). They are composed of fractured, lithoidal rhyolite, and are surrounded by talus, alluvial-fan deposits, and younger basaltic lava flows.

Five groups of Quaternary basaltic lava flows have been mapped in the INEL area (Figure 1). The groups were mapped based on geologic field relations, age dating (potassiumargon, radiocarbon, and paleomagnetic methods), degree of weathering, and thickness of sediment cover (Kuntz et al., 1994). Quaternary volcanic rocks, chiefly basaltic lava flows, are exposed over approximately $58 \%$ of the INEL and the adjacent land area, and occur in the subsurface across most of the ESRP. Figure 2 shows the relative areas covered by subaerially-exposed Quaternary volcanic rocks in the INEL region. Several aspects of Figures 1 and 2 are important for INEL volcanic-hazards assessment:

(1) More than two thirds of the subaerially-exposed basaltic lava and all of the silicic lava of the INEL land surface and adjacent areas is older than 200,000 years (Figure 2 - map units Qbc, Qbd, Qbe and Qr).

(2) No Holocene vents occur on the INEL, but Holocene basaltic lava flows (Qba) cover $12 \%$ of the ESRP in the INEL area and have erupted from vents along the axis of the ESRP as recently as 5,400 years ago.

A minuscule percentage of the INEL area is occupied by silicic volcanic domes (map unit Qr), and these features are located along the axis of the ESRP near the southern INEL boundary.

Relative to basaltic volcanism, silicic volcanism and its potential hazards are, therefore, expected to be infrequent and to affect small areas of the axial volcanic zone.

Volcanic vents are not randomly distributed on the ESRP, but lie chiefly along the axial volcanic zone (Figure 3), a northeast-trending, constructional-volcanic highland. Volcanic vents are also found in the southern portions of several northwest-trending volcanic rift zones where they merge with the axial volcanic zone (Figure 4). Volcanic rift zones are the surface expressions of 


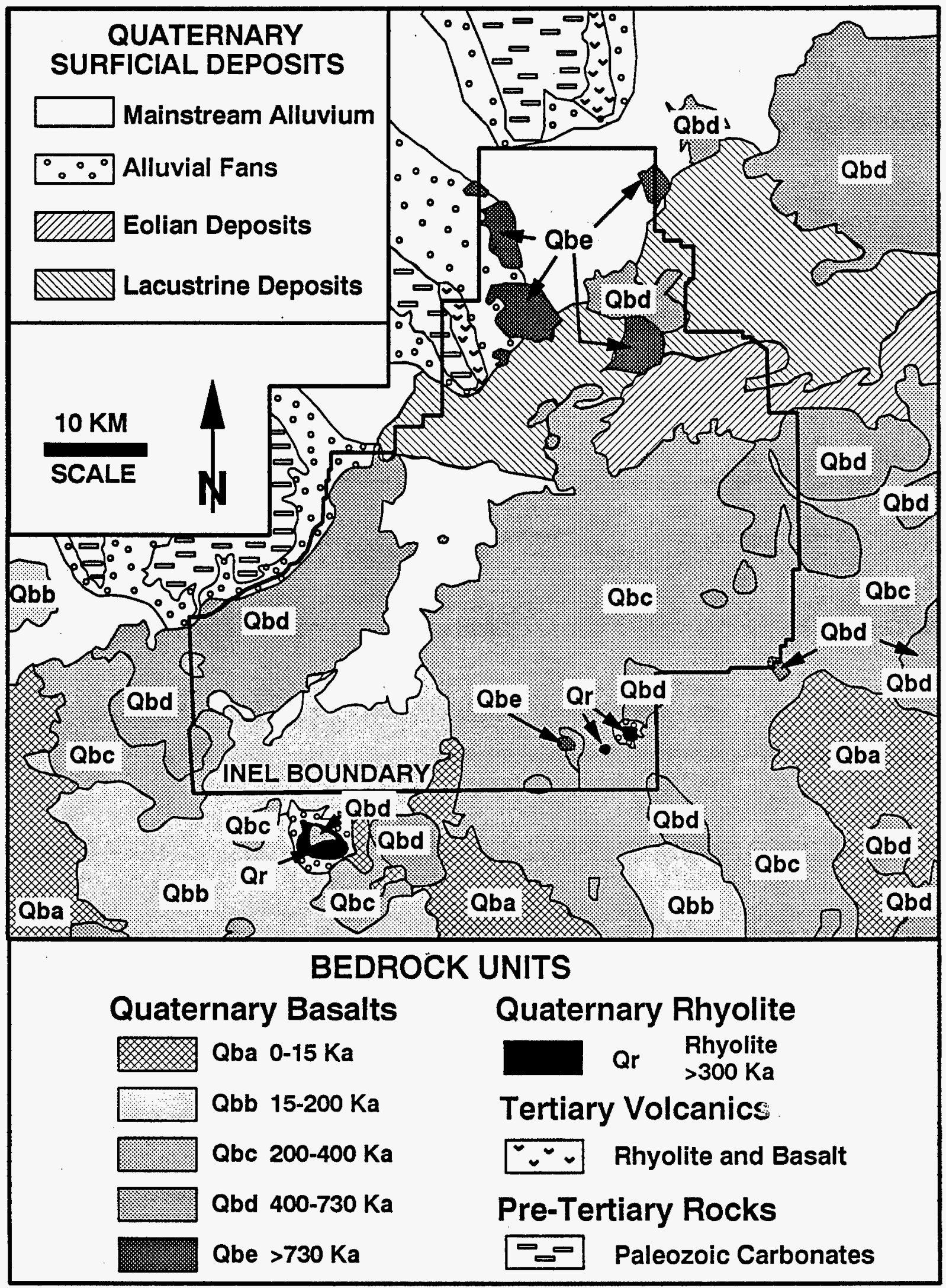

Figure 1. Generalized geologic map of the INEL area (adapted from Kuntz et al., 1990 and Scott, 1982). 


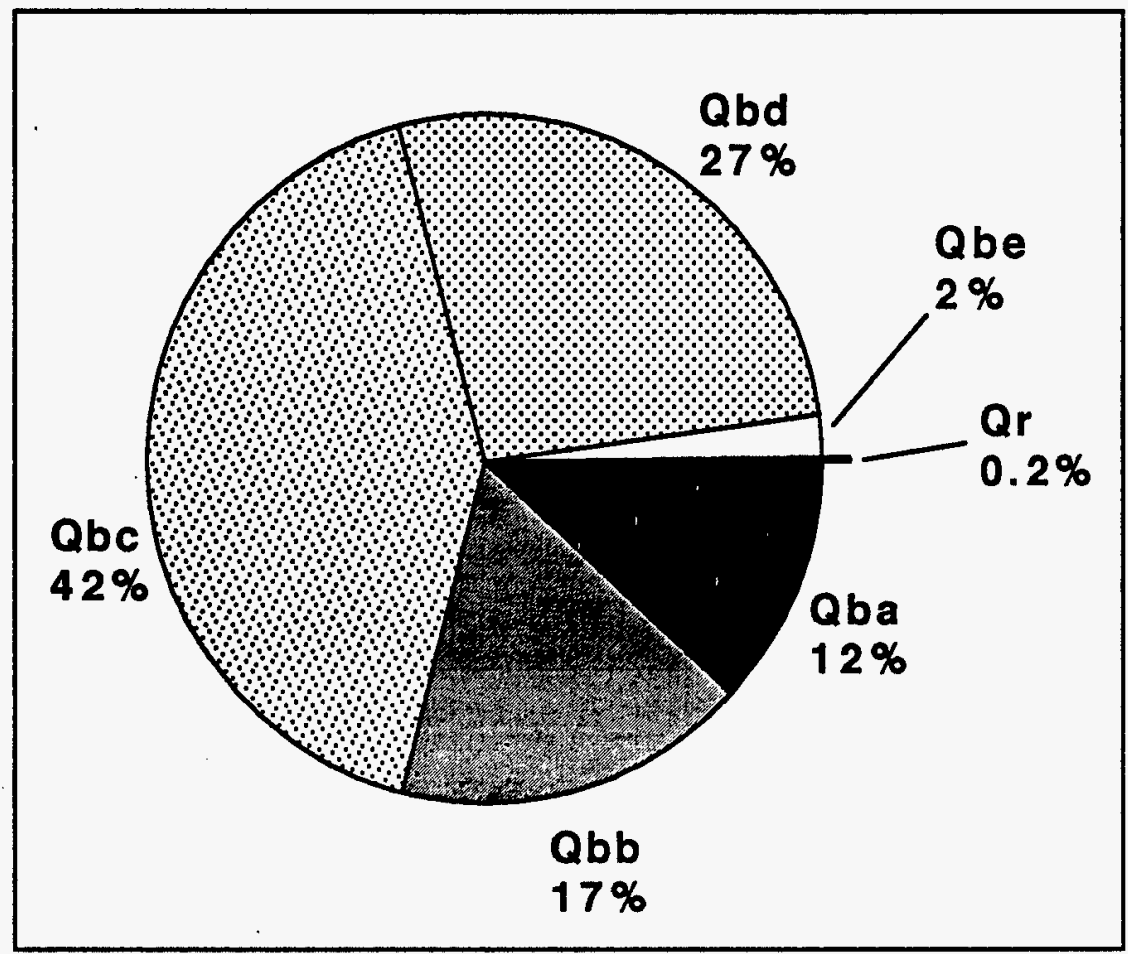

Figure 2. Relative areas of INEL Quaternary volcanic rocks in the INEL region. 


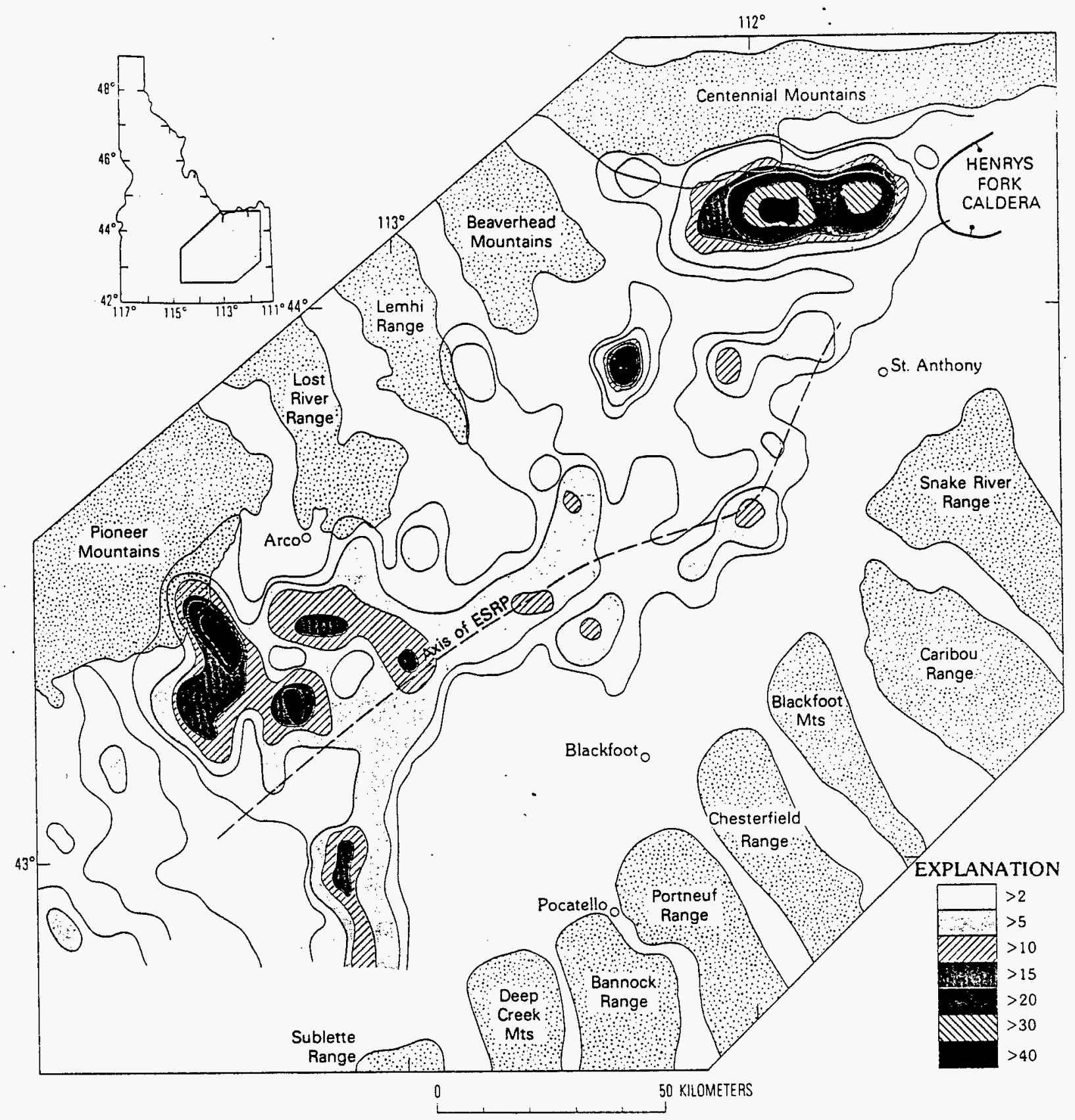

Figure 3. Number of volcanic vents per $140 \mathrm{~km}^{2}$ (approximate area of a 7.5 minute topographic quadrangle) in the eastern Snake River Plain (from Kuntz et al., 1992). 


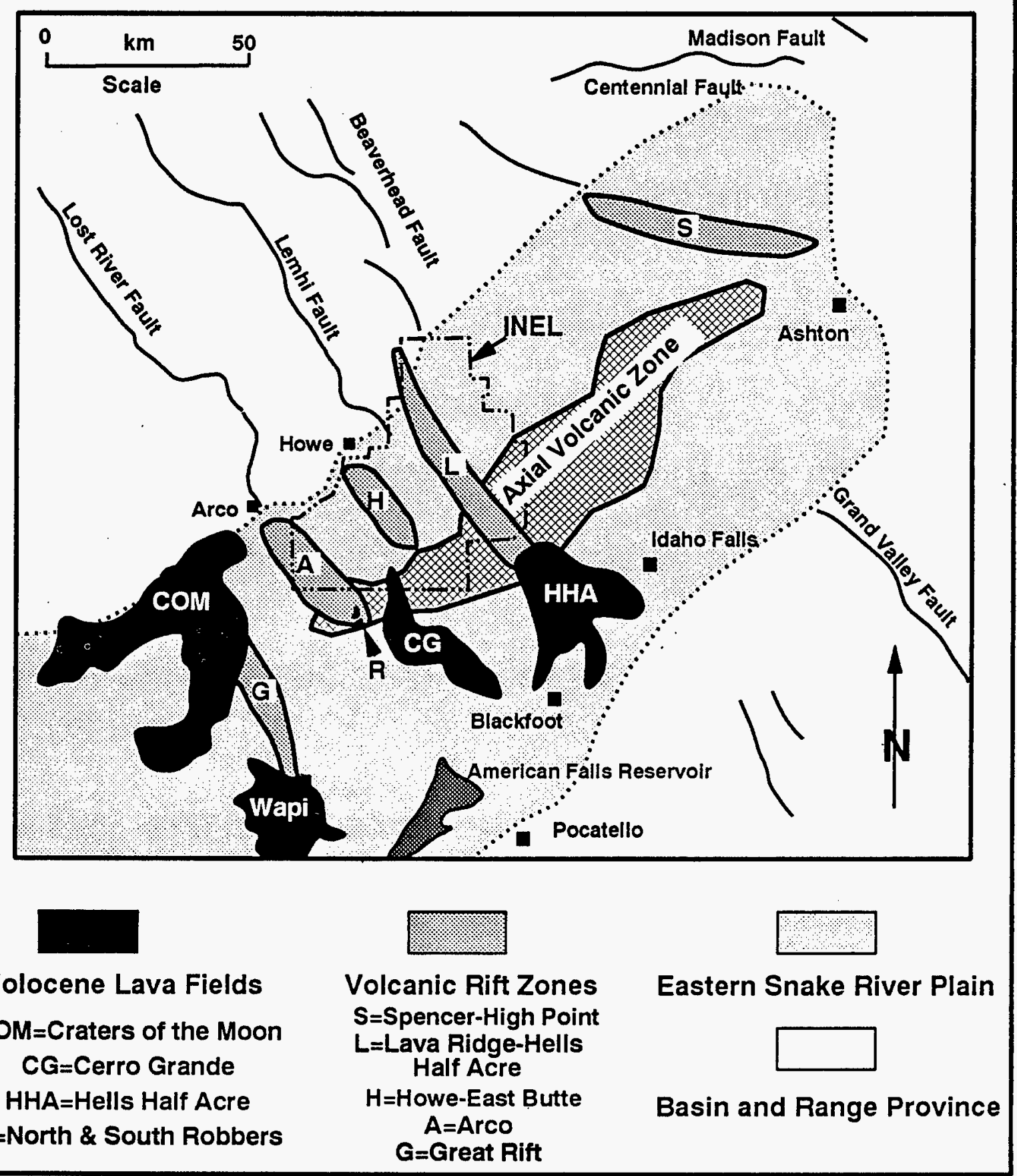

Figure 4. Map showing major volcanic and tectonic elements of the INEL area. 
underlying dike swarms. Dikes are magma-filled cracks, and where they intersect the earth's surface, lava flows erupt. During ascent, magma pressure forces overlying rocks apart, forming belts of extensional deformation above the dikes, consisting of open fissures, small normal-fault scarps and monoclines (Smith et al., 1989; Hackett and Smith, 1992; Kuntz et al., 1992). The volcanic rift zones are also marked by linear arrays of fissure-fed basaltic lava flows, small-shield volcanoes, pyroclastic cones, and pit craters. The ESRP volcanic rift zones are more diffuse than those of Hawaii, and their northwesterly orientation is controlled by the regional, northeastsouthwest extension of the ESRP and the adjacent Basin and Range Province, rather than by the intrusive and gravitative forces associated with growth of the huge Hawaiian shield volcanoes. However, discrete volcanic and structural features of ESRP volcanic rift zones are generally similar to the those developed in the Hawaiian and Icelandic rift zones. The axial volcanic zone exhibits fewer dike-induced fissures and faults than the volcanic rift zones because it has higher overall vent density and has been resurfaced more frequently by lava flows. Between the INEL volcanic rift zones are broad, low-lying basins such as the Big Lost River Sinks of the northern and central INEL. Borehole data suggest that these areas receive more sediment and fewer lava flows than the volcanic zones.

The main style of Quaternary ESRP basaltic volcanism is Hawaiian, involving mild effusions of fluid, gas-poor, pahoehoe lava flows from fissures and small-shield volcanoes. Many ESRP basalt flows are tube-fed (Greeley, 1982), as shown by the widespread collapse depressions developed along lava tubes throughout the region. Isolated Strombolian (mild pyroclastic) volcanism is marked by cinder and spatter cones situated on eruptive fissures, many of which occur along the axial volcanic zone. Examples include the summit-forming tephra cone of Cedar Butte, and the field of small basaltic tephra cones near Atomic City to the south of the INEL. Phreatomagmatic volcanoes (tuff cones and tuff rings) result from steam explosions during the interaction of rising basaltic magma with ground water. Such features do not occur in the INEL area, probably because the water table is too deep under much of the region, but are found elsewhere on the ESRP (Womer, et al., 1982; Hackett and Morgan, 1988).

\section{INEL VOLCANIC HAZARDS AND THEIR MITIGATION}

The INEL area has experienced predominately basaltic volcanism during the past 4 million years, and phenomena associated with basaltic volcanism are, therefore, the most important to INEL hazard assessment. Table 2 outlines the principal hazards associated with ESRP basaltic volcanism. Lava flows are the most common phenomenon and, therefore, the most significant hazard on the ESRP. Tilling and Peterson (1994) summarize field observations of active lava in Hawaii where maximum flow rates in lava tubes are 1-2 m/ $\mathrm{s}^{-1}$ (ca. 2-4 mph), but the average advance of broad lava flow fronts was only 0.4 to $7.4 \mathrm{~m} / \mathrm{min}^{-1}$ during the July 1983 episode of a Kilauea East Rift Zone eruptive period. Short-lived lava surges traveled as fast as $25 \mathrm{~m} / \mathrm{min}^{-1}$. Thus, lava flows travel relatively slowly and mainly threaten property by inundation or burning.

Gas release is universally associated with fissuring and eruption, but poisonous or asphyxiating gases are generally serious hazards only within a few hundred meters of vents. Several kilometers downwind, corrosive gases may cause respiratory irritation, affect crops and cause corrosion, but are more a nuisance than a threat to life and property. After cooling, heavierthan-air gases (carbon dioxide, sulfur, sulfur dioxide, hydrogen fluoride, and hydrogen chloride) may collect in closed topographic depressions, but in the INEL area this is not likely to be a 


\begin{tabular}{|c|c|c|c|}
\hline PHENOMENON & $\begin{array}{l}\text { RELATIVE } \\
\text { FREQUENCY }\end{array}$ & $\begin{array}{l}\text { SIZE OR AREA OF } \\
\text { INFLUENCE } \\
\end{array}$ & COMMENTS \\
\hline lava flow & common & \begin{tabular}{|l|}
$0.1 \mathrm{~km}^{2}$ to $400 \mathrm{~km}^{2}$ in \\
area, up to $25 \mathrm{~km}$ length \\
based on sizes of ESRP \\
lava flows of the past \\
400,000 years \\
\end{tabular} & $\begin{array}{l}\text { significant hazard; typical basaltic } \\
\text { phenomenon; lava from fissures or } \\
\text { shield volcanoes may inundiate large } \\
\text { areas downslope of vents }\end{array}$ \\
\hline $\begin{array}{l}\text { ground } \\
\text { deformation: } \\
\text { fissuring, faulting } \\
\text { and uplift } \\
\end{array}$ & $\begin{array}{l}\text { common; } \\
\text { associated with virtually } \\
\text { all shallow magma } \\
\text { intrusion and eruption }\end{array}$ & $\begin{array}{l}\text { fissuring could affect } \\
\text { areas to } 2 \times 10 \mathrm{~km} \text {; minor } \\
\text { tilting \& broad uplift in } \\
\text { areas to } 5 \times 20 \mathrm{~km} \\
\end{array}$ & $\begin{array}{l}\text { significant hazard; due to shallow dike } \\
\text { intrusion; "dry" intrusion may occur } \\
\text { without lava flows; affects smaller areas } \\
\text { than for lava inundation }\end{array}$ \\
\hline $\begin{array}{l}\text { volcanic } \\
\text { earthquakes }\end{array}$ & $\begin{array}{l}\text { common; } \\
\text { associated with magma } \\
\text { intrusion before and } \\
\text { during eruption }\end{array}$ & $\begin{array}{l}\text { maximum } M=5.5 \text { and } \\
\text { most events } M<4 ; \\
\text { ground vibration may } \\
\text { affect facilities within } \\
25 \mathrm{~km}\end{array}$ & $\begin{array}{l}\text { low to moderate hazard; swarms of } \\
\text { shallow earthquakes (<4 km focal } \\
\text { depth) occur as dikes propagate } \\
\text { underground }\end{array}$ \\
\hline $\begin{array}{l}\text { gas release } \\
\text { (toxic and corrosive } \\
\text { vapors) }\end{array}$ & $\begin{array}{l}\text { common; } \\
\text { associated with fissuring } \\
\text { and lava enuption }\end{array}$ & $\begin{array}{l}\text { restricted to near-vent } \\
\text { areas; may affect } \\
\text { several-square-km area } \\
\text { downwind }\end{array}$ & $\begin{array}{l}\text { low hazard; local plume of corrosive } \\
\text { vapor, downwind from eruptive vent or } \\
\text { fissure; cooled vapors may collect in } \\
\text { local topographic depressions }\end{array}$ \\
\hline $\begin{array}{l}\text { tephra fall } \\
\text { (volcanic ash and } \\
\text { bombs) }\end{array}$ & uncommon & as per gas release & $\begin{array}{l}\text { low hazard; basaltic eruptions are } \\
\text { inherently nonexplosive and may form } \\
\text { small tephra cones but little fine ash to } \\
\text { be carried downwind }\end{array}$ \\
\hline $\begin{array}{l}\text { base surge } \\
\text { (ground-hugging blast } \\
\text { of steam and tephra) }\end{array}$ & rare & $\begin{array}{l}\text { effects limited to radius } \\
\text { of several } \mathrm{km} \text { from vent; } \\
<10 \mathrm{~km}^{2} \text { area }\end{array}$ & $\begin{array}{l}\text { low hazard; steam explosions due to } \\
\text { interaction between ascending magma } \\
\text { and shallow groundwater; water table } \\
\text { too deep under most of INEL }\end{array}$ \\
\hline $\begin{array}{l}\text { tephra flow } \\
\text { (ground-hugging flow of } \\
\text { hot, pyroclastic material) }\end{array}$ & extremely rare & $\begin{array}{l}\text { near vent; may affect } \\
\text { area }<1 \mathrm{~km}^{2}\end{array}$ & $\begin{array}{l}\text { very low hazard; as per tephra fall but } \\
\text { affecting even smaller areas }\end{array}$ \\
\hline
\end{tabular}

Table 2. Hazards associated with basaltic volcanism on the Eastern Snake River Plain. Entries are listed from highest to lowest relative hazard. 
significant hazard, due to persistent winds and the broad expanse of most topographic basins on the INEL. The confined basin of the Big Lost River Sinks and the Birch Creek Sinks in the northcentral INEL may be an exception (Smith, 1994).

Explosive pyroclastic volcanism and significant tephra fall are rare during mild, Hawaiiantype eruptions such as those that characterize the ESRP. Tephra fallout would be largely restricted to deposition of volcanic bombs and cinders in areas within $100 \mathrm{~m}$ of volcanic vents. Tephrahazard areas are, therefore, similar in size and geometry to those of volcanic gases.

The growth of future silicic lava domes may occur along the axial volcanic zone, but the hazardous effects would largely be restricted to a several-kilometer radius. Historical observations of active silicic lava domes have shown that silicic domes commonly produce small-volume pyroclastic flows and tephra falls as a result of internal explosions and slope failure. However, no evidence of such deposits from silicic domes near the INEL has yet been identified through geologic mapping and borehole investigations. Shallow intrusion of silicic magma during the growth of lava domes may also lead to uplift of large tracts of ground. Middle Butte in the axial volcanic zone is a block of old (Qbe) lava flows that was presumably uplifted by a silicic lava dome that did not breach the surface (Kuntz and Dalrymple, 1979), and the emplacement of Big Southern Butte has raised a $900 \mathrm{~m}$ thick block of basalts on its northern flank (Spear and King, 1982; Fishel, 1993).

Indirect hazards associated with basaltic volcanism are ground deformation and seismicity associated with dike intrusion beneath volcanic rift zones. Surface fissuring and inflation occur during dike intrusion with or without volcanic eruption, and the major effects are restricted to narrow belts above the intruding dikes, generally less than $1 \mathrm{~km}$ wide and several kilometers in length. Tensile fissures on the ESRP have widths ranging from 0.1 to about $1 \mathrm{~m}$, and normal-fault displacements of several meters have been measured. Broader areas, up to about $5 \mathrm{~km}$ across, may be affected by imperceptible ground tilting as a result of inflation and uplift during dike intrusion. Small- to moderate-magnitude earthquakes are anticipated to occur during future dike intrusion, with maximum magnitudes estimated to be less than M 5.5 on the ESRP (Jackson, 1994; Smith et al., 1995 in press).

None of these volcanic phenomena can be effectively controlled, and the most successful mitigation will involve avoidance through careful land-use planning and site selection. Once a volcanic vent has become established, the paths of lava flows can usually be predicted by terrain analysis. In some situations, their courses can be modified by the construction of rock-rubble barriers (Barberi et al., 1993). Diversion barriers should be placed well upslope of threatened facilities, in opportune topographic positions, and not at the facilities themselves. Water has been used to chill and halt advancing lava flow fronts, but this requires enormous quantities of water and energy for pumping. It is generally not feasible to engineer structures to withstand ground fracturing or faulting, or the effects of corrosive gases. Tephra fall is not a significant hazard in the INEL area, and the mitigation of roof collapse or other effects is, therefore, unwarranted. 


\begin{tabular}{|c|c|c|c|c|c|}
\hline $\begin{array}{l}\text { VOLCANIC ZONE } \\
\text { OR BOREHOLE }\end{array}$ & \begin{tabular}{|l} 
DATA \\
SOURCES
\end{tabular} & \begin{tabular}{|l|} 
TIME INTERVAL \\
OF vOLCANISM \\
[yrs before present]
\end{tabular} & $\begin{array}{l}\text { NUMBER OF VENTS, } \\
\text { FISSURES OR FLOW } \\
\text { GROUPS }\end{array}$ & COMMENTS & $\begin{array}{l}\text { ESTIMATED } \\
\text { RECURRENCE } \\
\text { INTERVAL } \\
\end{array}$ \\
\hline $\begin{array}{l}\text { Great Rift } \\
(25 \mathrm{~km} \text { southwest of } \\
\text { INEL) }\end{array}$ & $\begin{array}{l}\text { Kuntz et al., } \\
1986,1988\end{array}$ & $\begin{array}{l}2,100-15,000 \text { yrs } \\
\text { (radiocarbon dating) }\end{array}$ & $\begin{array}{l}>100 \text { vents } \\
8 \text { Holocene eruptive } \\
\text { periods (each lasting a few } \\
\text { decades or centuries, and } \\
\text { each including multiple } \\
\text { flows and cones). }\end{array}$ & $\begin{array}{l}\text { no impact on INEL; } \\
\text { most recently and frequently } \\
\text { active of all ESRP rift zones; } \\
\text { thus provides minimum- } \\
\text { recurrence for entire ESRP; } \\
\text { most probable area of future } \\
\text { ESRP volcanism }\end{array}$ & $\begin{array}{l}2,000 \text { yrs } \\
\left(5 \times 10^{-4} / y r\right)\end{array}$ \\
\hline $\begin{array}{l}\text { Axlal Volcanlc Zone } \\
\text { (southern INEL) }\end{array}$ & $\begin{array}{l}\text { Kuntz et al., } \\
1986,1994\end{array}$ & $\begin{array}{l}5,000-730,000 \text { yrs } \\
\text { (K-Ar dating; } \\
\text { radiocarbon; } \\
\text { paleomagnetic data) }\end{array}$ & \begin{tabular}{|l|}
73 vents $\&$ fissure sets; \\
4 Holocene lava fields, \\
3 of them shared by \\
volcanic rift zones. \\
45 cogenetic vent/fiss gps \\
\end{tabular} & $\begin{array}{l}\text { could affect much of southern } \\
\text { INEL; most recently and } \\
\text { frequently active of all volcanic } \\
\text { zones that could impact INEL }\end{array}$ & $\begin{array}{l}16,000 \mathrm{yrs} \\
\left(6.2 \times 10^{-5} / \mathrm{yr}\right)\end{array}$ \\
\hline $\begin{array}{l}\text { Arco } \\
\text { Volcanic RIft Zone } \\
\text { (southwestern INEL) }\end{array}$ & $\begin{array}{l}\text { Kuntz, 1978; } \\
\text { Smith et al., } \\
1989 ; \text { Kuntz } \\
\text { et al., } 1994 \\
\end{array}$ & $\begin{array}{l}10,000-600,000 \text { yrs } \\
\text { (radiocarbon, K-Ar and } \\
\text { TL dating; } \\
\text { paleomagnetic data) }\end{array}$ & \begin{tabular}{|l|}
83 vents \& fissure sets; \\
2 Holocene lava fields. \\
35 cogenetic vent/fiss gps
\end{tabular} & $\begin{array}{l}\text { volcanism coüld affect } \\
\text { southwestern INEL }\end{array}$ & $\begin{array}{l}17,000 \mathrm{yrs} \\
\left(5.9 \times 10^{-5} / \mathrm{yr}\right)\end{array}$ \\
\hline $\begin{array}{l}\text { Lava Ridge-Hells } \\
\text { Half Acre Volcanic } \\
\text { Rift Zone (Includes } \\
\text { Clrc Butte/Kettle } \\
\text { Butte volc rift zone) } \\
\text { (north \& eastern INEL) } \\
\end{array}$ & $\begin{array}{l}\text { Kuntz et al., } \\
1986,1994\end{array}$ & $\begin{array}{l}5,000-1,200,000 \text { yrs } \\
\text { (K-Ar dating; } \\
\text { radiocarbon; } \\
\text { paleomagnetic data) }\end{array}$ & $\begin{array}{l}48 \text { vents \& fissure sets; } \\
1 \text { Holocene lava field: } \\
\text { Hells Half Acre. } \\
30 \text { cogenetic vent/fiss gps }\end{array}$ & $\begin{array}{l}\text { could affect northern \& } \\
\text { eastern INEL; extremely long } \\
\text { eruptive history; includes } \\
\text { oldest and youngest basalts in } \\
\text { the INEL area }\end{array}$ & $\begin{array}{l}40,000 \mathrm{yrs} \\
\left(2.5 \times 10^{-5} / \mathrm{yr}\right)\end{array}$ \\
\hline $\begin{array}{l}\text { Howe-East Butte } \\
\text { Volcanic Rift Zone } \\
\text { (central INEL) }\end{array}$ & $\begin{array}{l}\text { Kuntz, 1978, } \\
\text { 1992; Golder } \\
\text { Associates, } \\
1992 \\
\end{array}$ & $\begin{array}{l}230,000-730,000 \text { yrs } \\
\text { (K-Ar dating; } \\
\text { paleomagnetic data) }\end{array}$ & $\begin{array}{l}7 \text { vents \& fissure sets; } \\
\text { no Holocene features. } \\
5 \text { cogenetic vent/fissure } \\
\text { groups }\end{array}$ & $\begin{array}{l}\text { old, poorly exposed and } \\
\text { sediment-covered; identified } \\
\text { in part by subsurface } \\
\text { geophysical anomalies }\end{array}$ & $\begin{array}{l}100,000 \text { yrs } \\
\left(1.0 \times 10^{-5} / y r\right)\end{array}$ \\
\hline $\begin{array}{l}\text { Borehole } \\
\text { NPR SITE E } \\
\text { (south-central INEL) }\end{array}$ & $\begin{array}{l}\text { Champion et } \\
\text { al., } 1988\end{array}$ & $\begin{array}{l}230,000-640,000 \text { yrs } \\
\text { (K-Ar dating; } \\
\text { paleomagnetic data) }\end{array}$ & $\begin{array}{l}9 \text { lava-flow groups } \\
\text { (each group contains } \\
\text { multiple flows, erupted } \\
\text { over a short time) } \\
\end{array}$ & $\begin{array}{l}\text { dates from } 600 \text {-foot interval of } \\
\text { subsurface lavas give recur- } \\
\text { rence estimate consistent with } \\
\text { surficial geology of the area }\end{array}$ & $\begin{array}{l}45,000 \mathrm{yrs} \\
\left(2.2 \times 10^{-5} / \mathrm{yr}\right)\end{array}$ \\
\hline $\begin{array}{l}\text { Borehole } \\
\text { RWMC 77-1 } \\
\text { (southwestern INEL) }\end{array}$ & $\begin{array}{l}\text { Kuntz, 1978; } \\
\text { Anderson \& } \\
\text { Lewis, } 1989\end{array}$ & $\begin{array}{l}100,000-565,000 \text { yrs } \\
\text { (K-Ar and TL dating; } \\
\text { paleomagnetic data) }\end{array}$ & $\begin{array}{l}11 \text { lava-flow groups (each } \\
\text { group contains multiple } \\
\text { flows, erupted over a short } \\
\text { time) }\end{array}$ & $\begin{array}{l}\text { dates from } 600 \text {-foot interval of } \\
\text { subsurface lavas give longer } \\
\text { recurrence interval than } \\
\text { nearby Arco \& Axial zones, } \\
\text { reflecting flow-group (sub- } \\
\text { surface) vs. vent-counting } \\
\text { (surface geology) approaches }\end{array}$ & $\begin{array}{l}45,000 \mathrm{yrs} \\
\left(2.2 \times 10^{-5} / \mathrm{yr}\right)\end{array}$ \\
\hline
\end{tabular}

Table 3. Estimated volcanic-recurrence intervals and corresponding annual eruption probabilities (in parentheses) for volcanic zones and boreholes of the INEL area. 


\section{INEL VOLCANIC RECURRENCE}

\subsection{Methods of Estimating Volcanic Recurrence}

In developing the recurrence estimates of Table 3, effort has been devoted to establishing the number of vents and fissure sets to be counted for each INEL volcanic zone. Interpreting each lava flow, vent or fissure as the product of a discrete volcanic eruption would be highly conservative (yield shortest recurrence intervals), and this procedure can be used to establish bounding conditions for volcanic recurrence. Equating individual lava flows, vents, or deformation features as the products of single eruptions would generally shorten the preferred recurrence estimates of Table 3 by factors of 1.5 to 3 . This procedure is geologically incorrect because single eruptions usually produce several vents along a common eruptive fissure, and nearly always produce multiple lava flows and surface-deformation features.

Field and petrographic investigations were undertaken to develop a defensible, geologically correct procedure for grouping vents and fissures into cogenetic sets, leading to appropriately conservative recurrence estimates for the INEL volcanic zones. The geologic map of Kuntz et al. (1994) shows individual vents and fissures, and the paths and chronology of lava flows. This map information has been supplemented with investigations by W. R. Hackett and by S. M. Hughes (letter report to EG\&G Idaho, Inc., February 1994). The field relations of selected vent areas and basaltic lava flows were examined in the axial volcanic zone and the southern Arco volcanic rift zone, and aerial photographs were also examined. Petrographic features of basalt lava flows were qualitatively described in the field, and thin sections of selected lava flows were analyzed. The purpose of these investigations was to develop field-scale geologic and petrographic criteria for recognizing the cogenetic products of single eruption cycles, particularly cogenetic groups of lava flows and dike-induced fissures associated with individual shield volcanoes. Two main conclusions were reached: (1) The field and aerial-photograph investigations showed that the geologic-map relations of Kuntz et al. (1994) reliably depict the configurations, relative ages and source vents of basaltic lava flows in the INEL area. Rather than an evaluation of the quality of the published mapping, this is important confirmation that geologic field relations as mapped at 1:100,000 scale by Kuntz et al. (1994) are adequate for INEL volcanic-hazards assessment, because the products of individual eruptions are readily distinguished at that scale. (2) Lava flows from individual shield volcanoes are petrographically similar and can be distinguished from lavas of other vents by noting differences in phenocryst content, and groundmass mineralogy and texture. The petrographic findings support our working hypothesis that small ESRP volcanic centers, such as the shield volcanoes and other vents targeted in the study, are the products of compositionally uniform magma batches, and each shield or spatially related group of vents can generally be interpreted as the product of a single volcanic-eruption cycle. Most ESRP volcanoes are small, monogenetic features, as shown by the field relations and by the overall petrographic uniformity among lava flows from the individual shield volcanoes and vent complexes examined. In the southern Arco volcanic rift zone, the petrographic similarities and field relations among several of the shield volcanoes suggest that in places, several shield volcanoes may be the cogenetic products of a single magma batch.

Cedar Butte, a large central volcano of the axial volcanic zone (Hayden, 1992), is an exception to the typically monogenetic volcanism of the INEL area. At this polygenetic eruptive center, several eruption cycles have produced diverse lava compositions ranging from basalt to 
rhyolite, and pyroclastic as well as effusive volcanism, suggesting a complex magma system that evolved either by protracted differentiation of a single batch of parental magma, or by magmareservoir replenishment.

In circumstances where a noneruptive fissure or fissure set cannot confidently be tied to cogenetic volcanic materials, the fissure(s) were nonetheless counted as one "vent" (i.e., were conservatively interpreted as the products of one noneruptive dike-intrusion event). An example is the single, isolated monocline that exists in the central Lava Ridge - Hell's Half Acre volcanic rift zone. Other examples are the fissures, normal-fault scarps and monoclines of the northern Arco volcanic rift zone. These features are conservatively treated in this report as youthful, dike-induced structures associated with Qbc (less than 400,000 years) or younger volcanism. However, some of the northernmost normal-fault scarps and monoclines of the Arco volcanic rift zone may be nonvolcanic in origin, and related to tectonic displacement along the Arco segment of the Lost River fault.

Within the INEL volcanic zones, vents and fissures are thus grouped into cogenetic sets, each set inferred to be the product of a magma batch that was erupted or intruded during a geologically brief period. Geologic and geophysical observations during historical rift-zone volcanism in Hawaii and Iceland show that dike intrusion, ground deformation, and lava flow effusion are cogenetic phenomena that develop during geologically brief eruptive periods of several weeks to a decade or so. The inference that multiple lava flows and vents on the ESRP are cogenetic and form during brief periods is further supported by paleomagnetic data from drillcores of INEL lava flows (Champion et al., 1988), and by radiocarbon dates from Holocene lava flows in Craters of the Moon lava field (Kuntz et al., 1986; 1988).

\subsection{Recurrence Estimates}

The recurrence estimates for INEL volcanic zones and boreholes given in Table 3 are based chiefly on the geochronology and geologic map data of Kuntz et al. (1994). Results have been rounded off to avoid implying undue precision, and are expressed as frequencies of eruption and as annual probabilities of occurrence. Eruptive periods are separated by an average of about 2,000 years for the Great Rift, corresponding to an annual probability of $5 \times 10^{-4} \mathrm{yr}^{-1}$. Future eruptions of the Great Rift would have little or no impact upon the INEL, but the data are included because this volcanic rift zone has been thoroughly studied and has been frequently active during the past 15,000 years. Its 2,000 -year recurrence interval serves as a bounding value of shortest recurrence for the ESRP as a region.

Northwest-trending volcanic rift zones of the INEL area overlap with the axial volcanic zone (Figure 4), and volcanic vents in the areas of overlap are counted as belonging to both the axial volcanic zone and the respective volcanic rift zones. This is a conservative procedure that leads to short recurrence estimates (highest frequencies) of volcanism for the volcanic rift zones, but is justified in the absence of defensible criteria for assigning those vents solely to the axial volcanic zone. The shortest recurrence intervals (greatest annual probabilities of eruption) for INEL volcanic zones are approximately 16,000 years $\left(6.2 \times 10^{-5} \mathrm{yr}^{-1}\right)$ for the axial volcanic zone and the Arco volcanic rift zone. The axial volcanic zone has the greatest number of volcanic vents of the INEL volcanic zones, and includes four Holocene lava fields. The Arco volcanic rift zone has more vents than other INEL-area volcanic rift zones, and also the greatest number of fissures 
and faults due to dike intrusion. Together, these two zones account for more than two thirds of the volcanic vents and dike-induced fissure sets in the INEL area.

Throughout this report, and for purposes of recurrence estimation, the Circular ButteKettle Butte volcanic rift zone of Kuntz et al. (1992) and the Lava Ridge-Hell's Half Acre volcanic rift zone are combined into a single entity. They are diffuse, adjacent features with similar characteristics, timing and recurrence. Although the number of vents is similar to the Arco volcanic rift zone, the 40,000-year recurrence estimate for the Lava Ridge-Hell's Half Acre volcanic rift zone is longer, because the lava flows of its northern part are 1.2 million years old, and are among the oldest lavas known from the INEL area.

The Howe-East Butte volcanic rift zone, included in Table 3, is identified by Kuntz et al. (1992), but is poorly expressed in the INEL surficial geology. In its northern part, this rift zone has a few vents and fissures developed within lava flows older than about 400,000 years (Qbd map unit). In contrast to other ESRP volcanic rift zones, its central part is not a topographic highland, but is a basin containing Big Lost River sediment and younger lava flows from other volcanic zones. Vents that may comprise its southern portion are considered in this report to be part of the axial volcanic zone. The Howe-East Butte volcanic rift zone is marked by a large, northwest-trending, positive aeromagnetic anomaly, which may represent a major subsurface dike swarm. If so, the feature might best be interpreted as an old volcanic rift zone that is now largely covered by younger volcanic and sedimentary deposits. The stated time interval (Table 3) of 230,000 to 730,000 years is very conservative because it allows for fissuring and volcanism as young as 230,000 years. Nonetheless, the 100,000 -year recurrence is the longest of any INEL volcanic zone.

Expansion of the time intervals of volcanism to the present (zero million years) would be a valid consideration for the INEL volcanic zones, because hazard assessments are necessarily concerned with the potential effects of future volcanism. However, this would not substantially change the recurrence estimates for the INEL volcanic zones because most of them, excepting the Howe-East Butte volcanic rift zone, include lava flows younger than about 12,000 years.

Just as volcanic hazards will generally decrease with distance from vents, so also does volcanic recurrence decrease within a volcanic zone, as the volcanism becomes older and the number of vents within the zone becomes smaller. Thus, the northern parts of the Arco- and Lava Ridge - Hell's Half Acre volcanic rift zones contain fewer and older volcanic vents than their southern portions near the axial volcanic zone, and volcanic recurrence within these rift zones decreases northward. The recurrence estimates reported for the Arco- and Lava Ridge - Hell's Half Acre volcanic rift zones should be interpreted as average values for those rift zones.

Borehole data are also shown in Table 3 for comparison with the surface volcanic zones. Borehole recurrence estimates are similar to those of the volcanic zones, although a different method is necessarily used to estimate subsurface recurrence. For example, in the NPR Site E borehole, there are nine basaltic lava flow groups, separated by sedimentary interbeds.

Paleomagnetic data indicate that the lava flow groups were emplaced within relatively brief periods of centuries to millennia, during the 400,000-year dated interval of the borehole. Each lava flow group may, therefore, be interpreted as the product of one or a few closely spaced eruption cycles, 
perhaps representing the lava flows from several coalesced shield volcanoes. Nine eruption cycles (lava flow groups) per 400,000 years gives the 45,000-year recurrence estimate for this borehole.

\section{LENGTHS AND AREAS OF INEL BASALT LAVA FLOWS}

To provide a quantitative basis for defining the INEL lava flow hazard zones, the lengths and areas of 116 lava flows from the five Quaternary basaltic lava flow groups of Kuntz et al. (1994) were measured, and statistical parameters were compiled for the lava flow lengths and areas. The results are graphically presented in Figures 5 and 6 and Table 4 provides a statistical summary of the data. Lava flow length is used as an important parameter in defining the INEL lava flow hazard zones. Data from the three youngest Quaternary lava flow groups ( $\mathrm{Qb}$ a, b, c; younger than 400,000 years) are most relevant to hazards assessment for several reasons.

Younger lava flows represent the most recent volcanism. In addition, the smaller lengths and areas of lavas from the older flow groups Qbd and Qbe, evident in the graphical and statistical summaries, are unrepresentative of original lava flow dimensions, and are almost certainly the result of coverage by younger volcanic and sedimentary materials.

The three youngest flow groups ( $\mathrm{Qb}$ a, b, c; Table 4, frames 2 and 4) together represent about half of the total population of measured INEL lava flows. No lava flow in the INEL area has traveled farther than about $25 \mathrm{~km}$ from its source. Lengths vary by about a factor of 5 , the mean flow length is $8 \mathrm{~km}$, and the length distribution is strongly skewed toward short flows. The average INEL lava flow of the past 400,000 years covered 47.1 square $\mathrm{km}$. Comparison of the length statistics with the area statistics of INEL basaltic lavas illustrates their general geometry. The ratio of mean length $(8 \mathrm{~km})$ to mean width $(6 \mathrm{~km})$ is about 1.3. Thus, the average lava flow on the ESRP is nearly equant, reflecting the tendency of basaltic lavas to spread laterally on the gently sloping, low-relief terrain.

\section{INEL HAZARD ZONE MAPS}

Volcanic hazard zones are founded on the assumption that future eruptions will be similar to those of the past, as reconstructed from the INEL geologic record. A qualitative approach to hazard analysis and mapping would be to simply assign the highest hazard zones to the fissure swarms and areas with the greatest number of volcanic vents, but a requirement of this report was to develop a quantitative basis for hazard analysis and mapping. The quantitative approach used here incorporates several primary and secondary criteria. Primary criteria are:

(1) the location and density (number per unit area) of dike-induced fissures;

(2) location and density of the most recent lava flows;

(3) volcanic recurrence, estimated from the sum of cogenetic fissure sets and volcanic vents within each of the INEL volcanic zones, together with the absolute chronology of the volcanic materials (Figure 7); and

(4) distance from volcanic vents or zones. 


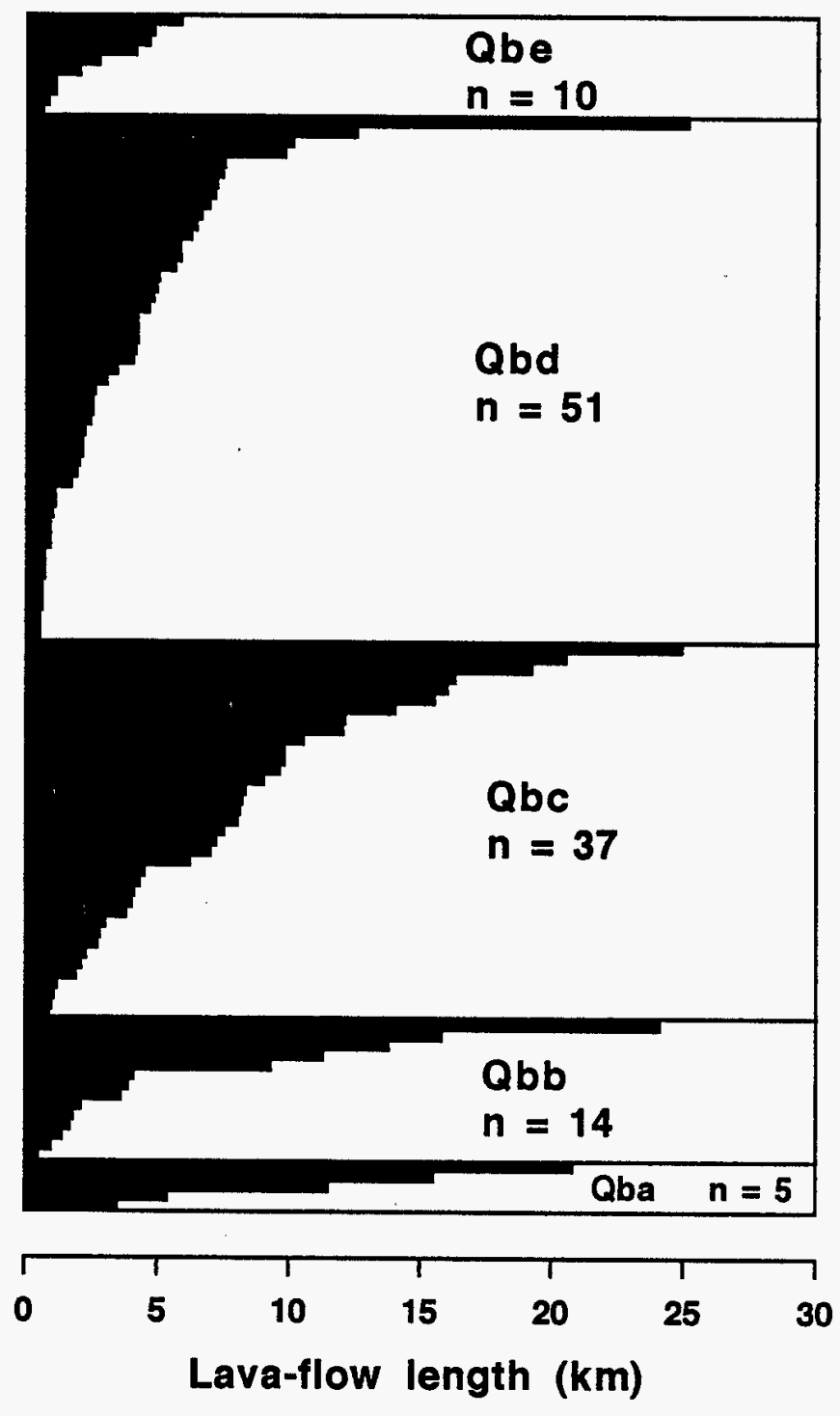

Figure 5. Lengths of INEL Quaternary basaltic lava flows, measured from map data of Kuntz et al., (1994). Qba through Qbe refer to basalt map units; " $n$ " values give the number of flows measured within each map unit. 


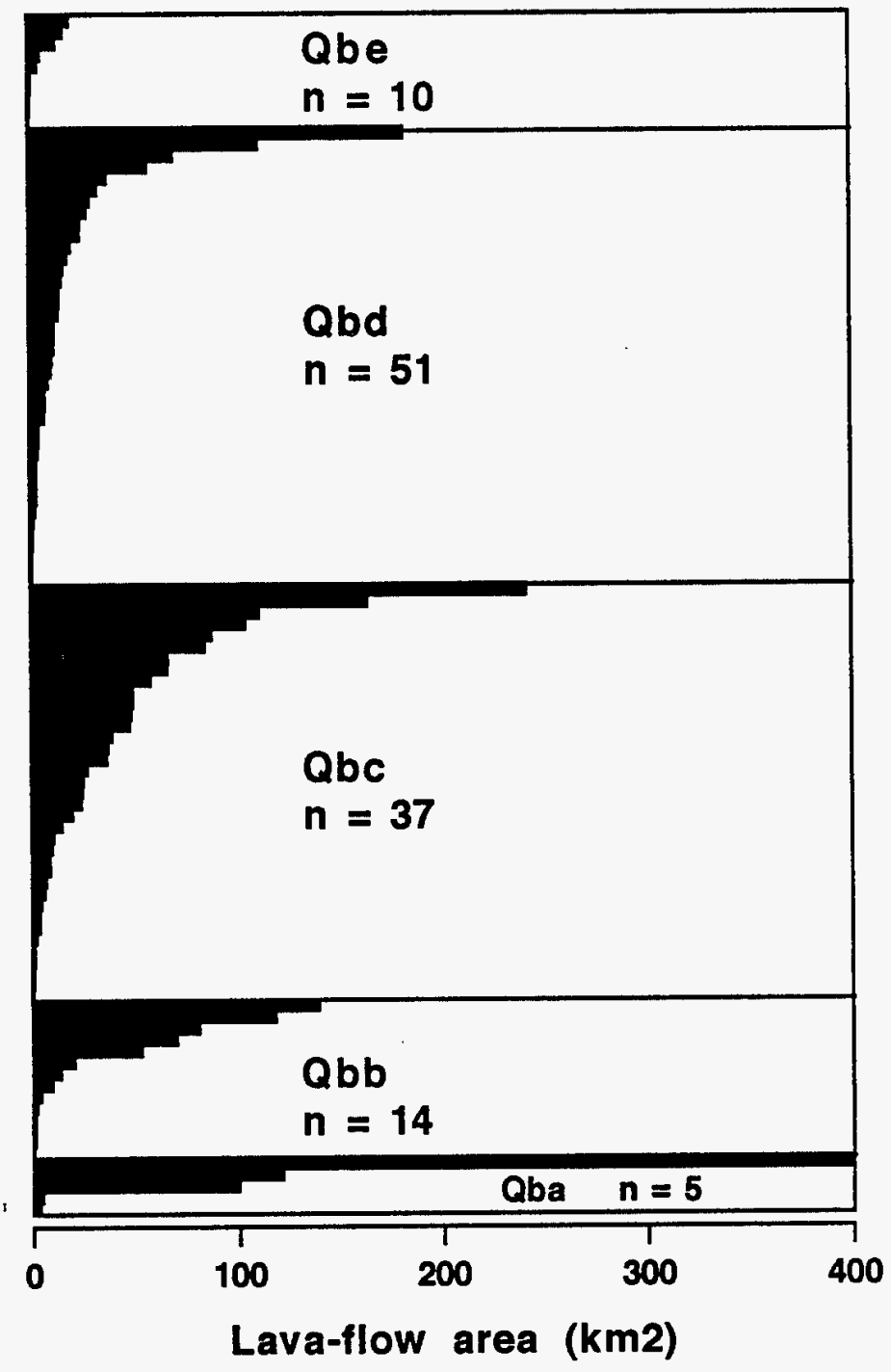

Figure 6. Areas of INEL Quaternary basaltic lava flows, measured from map data of Kuntz et al., 1994. Qba through Qbe refer to baslat map units; " $n$ " values give the number of flows measured within each map unit. 


\begin{tabular}{|r|r|}
\hline \multicolumn{2}{|l|}{ Qb abcde length stats $(\mathbf{k m})$} \\
\hline Minimum & 0.5 \\
\hline Maximum & 25.1 \\
\hline Range & 24.6 \\
\hline Mean & 5.9 \\
\hline Median & 4.1 \\
\hline St. Dev. & 5.6 \\
\hline Count & 117 \\
\hline
\end{tabular}

\begin{tabular}{|r|r|}
\hline \multicolumn{2}{|l|}{ Qb abc length stats (km) } \\
\hline Minimum & 0.5 \\
\hline Maximum & 24.9 \\
\hline Range & 24.4 \\
\hline Mean & 8 \\
\hline Median & 6.6 \\
\hline St. Dev. & 6.4 \\
\hline Count & 56 \\
\hline
\end{tabular}

\begin{tabular}{|r|r|}
\hline \multicolumn{3}{|l|}{ Qb abcde area stats (km2) } \\
\hline Minimum & 0.1 \\
\hline Maximum & 400 \\
\hline Range & 399.9 \\
\hline Mean & 30 \\
\hline Median & 9.6 \\
\hline St. Dev. & 55.1 \\
\hline Count & 116 \\
\hline
\end{tabular}

\begin{tabular}{|r|r|}
\hline \multicolumn{2}{|l|}{ Qb abc area stats (km2) } \\
\hline Minimum & 0.1 \\
\hline Maximum & 400 \\
\hline Range & 399.9 \\
\hline Mean & 47.1 \\
\hline Median & 20.1 \\
\hline St. Dev. & 70.6 \\
\hline Count & 55 \\
\hline
\end{tabular}

Table 4. Statistical summary of lava flow lengths and areas of INEL Quaternary basalts. Data for surficial lava flow groups Qb a-e are shown in Frames 1 and 3. Younger lava flows of groups $\mathrm{Qb}$ a-c are shown in Frames 2 and 4. Statistics of the younger lava flow groups are more relevant to hazards assessment. 


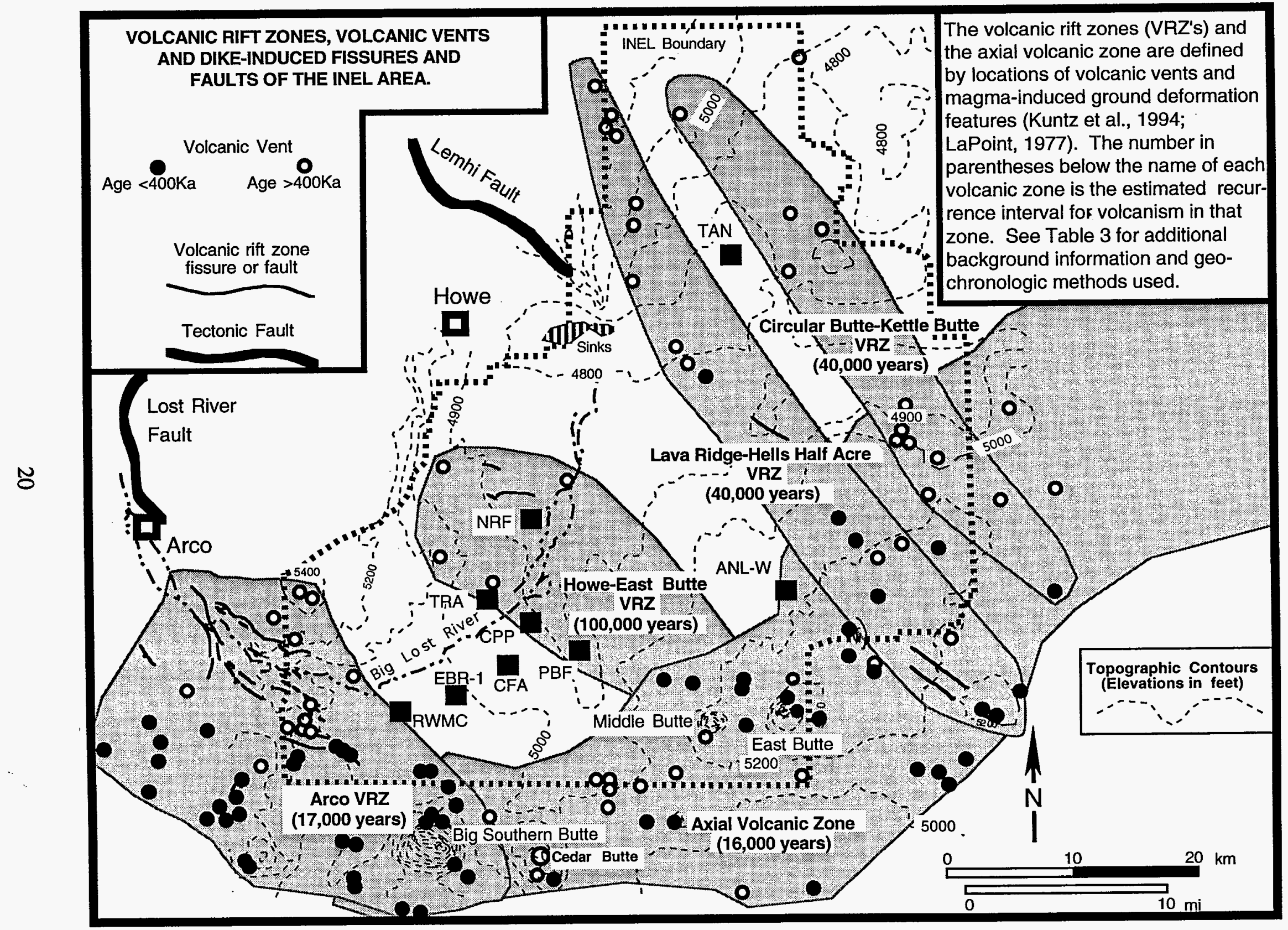

Figure 7. Map showing volcanic vents and volcanic recurrence intervals for volcanic zones in the INEL area. 
Secondary criteria include:

(1) topographic gradients and barriers that could affect the paths of lava flows or collect volcanic gases; and

(2) prevailing wind directions, which would affect the distribution of gases and fine tephra.

Volcanic-hazard zonation maps are given for lava flows (Figure 8), tephra fall and volcanic gases (Figure 9), and ground deformation associated with basaltic-dike intrusion (Figure 10). The hazard zone maps show areas in which the level of hazard differs from that of adjacent areas. The level of hazard may vary considerably within a zone, either gradually or abruptly. Direct volcanic hazards (lava flows, tephra, and gases) decrease gradually across zones and away from vents, but abrupt changes may occur along sharp topographic features. The degree of hazard changes gradually rather than abruptly across most zone boundaries, and zones would be most accurately rendered by gradational changes in shading rather than as sharp lines. The zone boundaries are rendered as a way of showing that differences in hazard exist, and to facilitate description of the zones. In spite of these limitations, the hazard zone maps and associated volcanic-recurrence data are useful for land-use planning, site selection, safety analysis, and long-range mitigation planning for volcanic hazards.

\subsection{Lava Flow Hazard Zones}

The length statistics of Quaternary basaltic lava flow groups $\mathrm{Qb} a, \mathrm{~b}$, and $\mathrm{c}$ are used to delineate hazard zones for lava inundation from vents within the INEL volcanic zones (Figure 8). Hazard Zone 1 (highest hazard) for lava flows is defined as being within $8 \mathrm{~km}$ of a Qb a, b or c vent or fissure. Eight kilometers is the mean lava flow length of $\mathrm{Qb} \mathrm{a}, \mathrm{b}$, and $\mathrm{c}$ flows (Table 4), meaning that random sites within zone 1 are statistically expected to be inundated by about $50 \%$ of lava flows that may erupt from nearby sources. The general probability of inundation at the outer limit of zone 1 is, therefore, less than or equal to half the annual eruption probability for its adjacent source volcanic zone, ignoring topographic and other site-specific factors. Hazard Zone 2 is an area of lower hazard, defined as being within $14 \mathrm{~km}$ (the mean length plus one standard deviation) of $\mathrm{a} \mathrm{Qb} \mathrm{a}, \mathrm{b}$ or $\mathrm{c}$ vent or fissure. Thus, on a statistical basis, less than $14 \%$ of erupted lava flows are expected to reach the outer limits of Hazard Zone 2. A further implication is that areas beyond Hazard Zone 2 will be inundated by $14 \%$ or less of future lava flows and these outlying areas, therefore, have probabilities of inundation that are at least an order of magnitude smaller than recurrence values of the nearest volcanic zones.

No fissuires on the INEL have yet been directly dated, and the ages of host volcanic rocks only serve to limit the maximum ages of fissures. Hence, all magma-induced fissures are conservatively assumed to be equivalent in age to younger lava flow groups than those of their host rocks. For example, most dike-induced faults and fissures of the northern Arco volcanic rift zone are developed in Qbd lava flows, but some of them could have formed during Qbc or younger volcanism and they are, therefore, included as potential sources of lava in defining lava flow Hazard Zone 1. On the other hand, the isolated fissures mapped near the Naval Reactors Facility by Golder Associates (1992) trend east-west, have an equivocal relationship to volcanic vents in 


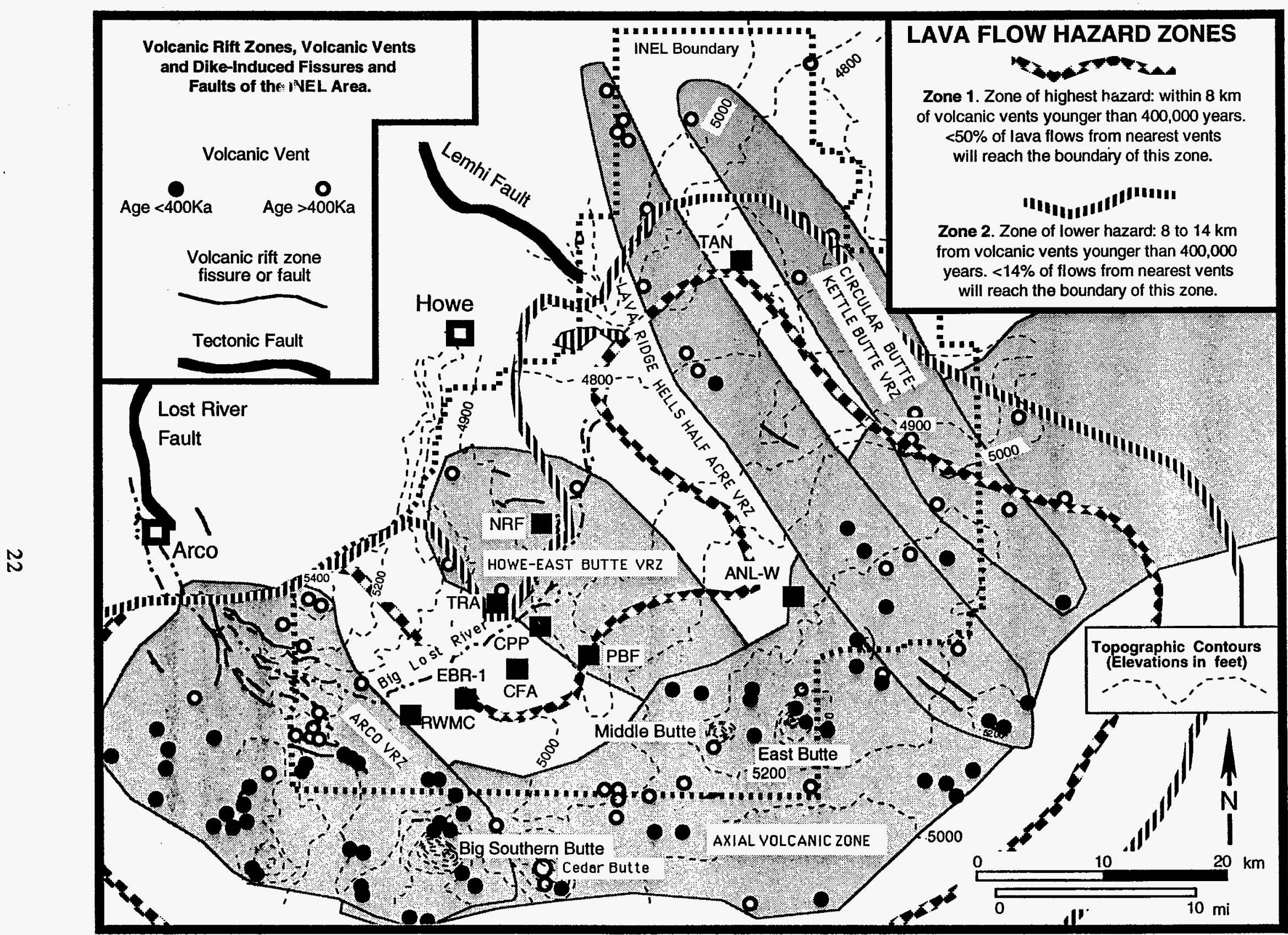

Figure 8. Lava flow hazard zone map of the INEL area: 


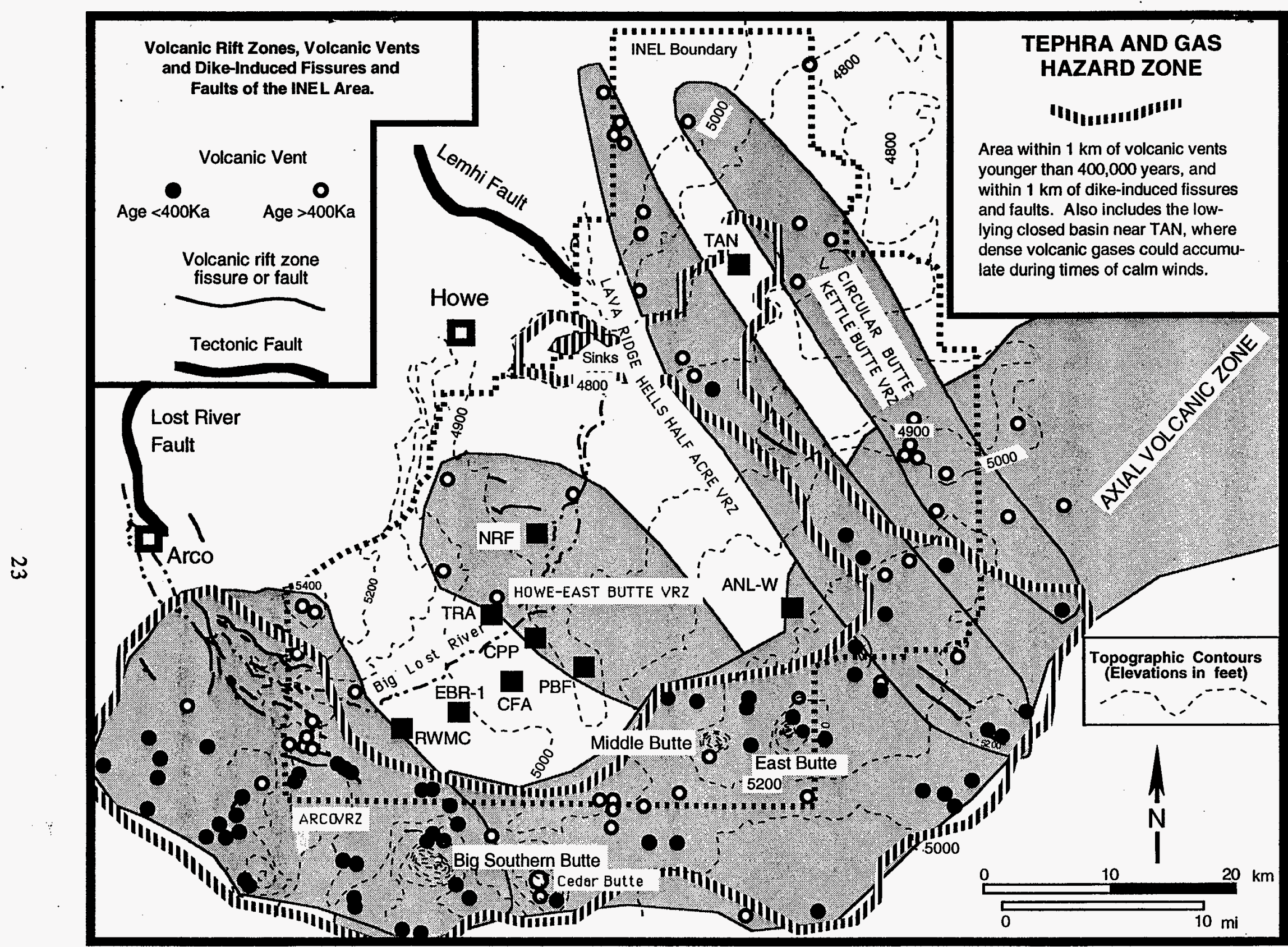

Figure 9. Tephra (ash) and gas hazard zone map of the INEL area. 


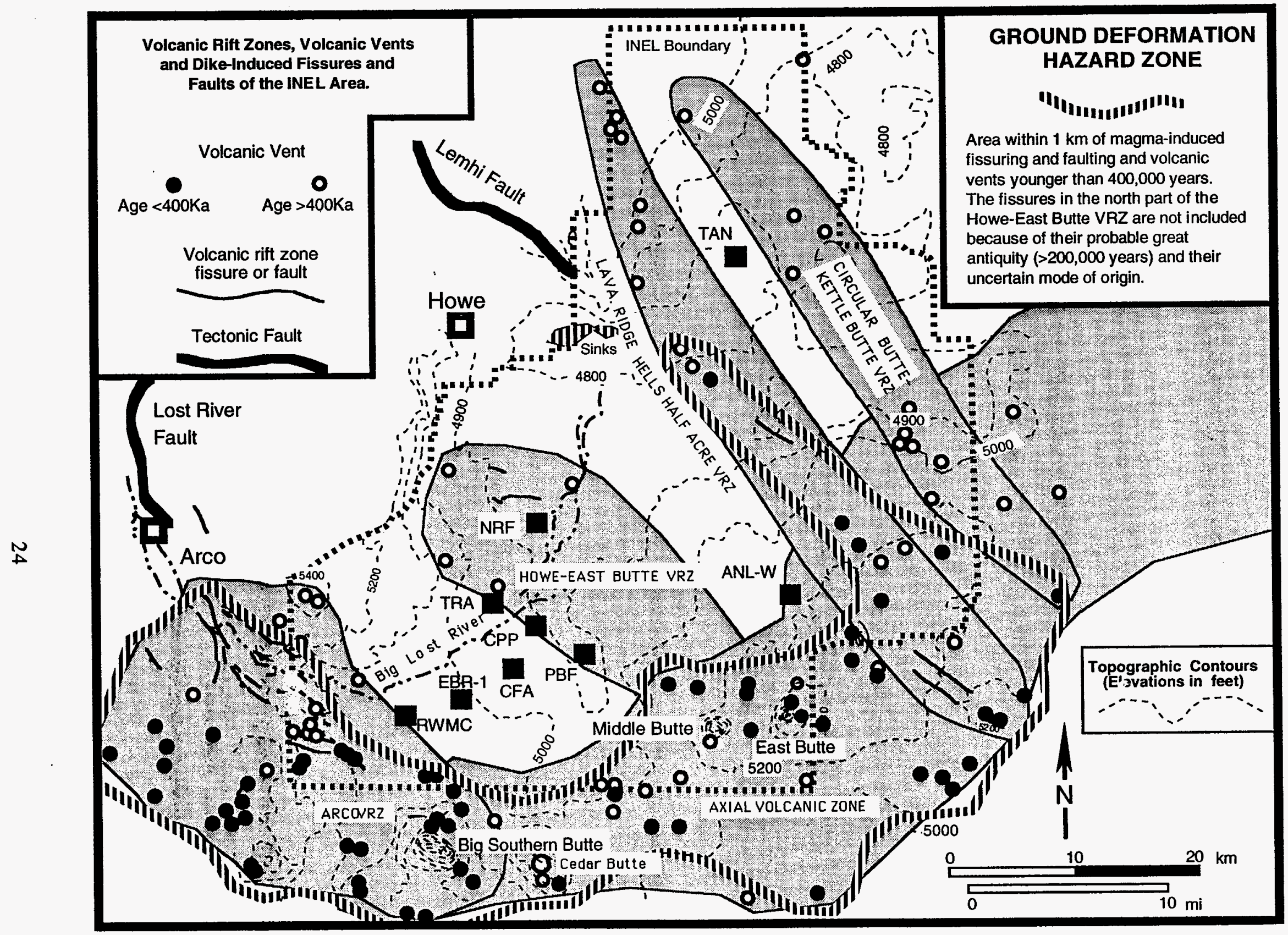

Figure 10. Ground deformation hazard zone map for the INEL area. 
the area, and may be related to basin subsidence rather than dike intrusion. These features occupy the northern part of the nebulous Howe-East Butte volcanic rift zone, and are not considered a likely site of future intrusion or eruption.

The lava flow hazard zones are truncated in the northern and western INEL, due to the topographic effects of mountain ranges near the northwestern INEL boundary, the south-sloping alluvial surfaces from those ranges and issuing from intermontane valleys, and the Big Lost River channel of the central INEL. Areas beyond zone 2 are sufficiently distant or uphill from the volcanic zones to be considered low-hazard areas, beyond the range of almost all lava flows.

\subsection{General Probabilities of Eruption and Lava Flow Inundation}

The statistics of lava flow lengths and the recency of volcanism $(\mathrm{Qb} \mathrm{a}, \mathrm{b}$, and $\mathrm{c}$ vent locations) are the primary criteria for defining the lava flow hazard zones, but recurrence estimates are also shown on Figure 7 to convey the frequencies of past basaltic volcanism within the INEL volcanic zones. The recurrence data of Table 3, which show annual eruption probabilities for each of the INEL volcanic zones, can be used in conjunction with lava flow statistics to construct statements of general probability for lava flow inundation within each of the INEL volcanic zones. The axial volcanic zone (16,000-year recurrence) provides a bounding value of eruption probability for the INEL volcanic zones, because it has erupted most frequently, and because the southern parts of the Arco- and Lava Ridge-Hell's Half Acre volcanic rift zones merge with it. The northern segments of the Arco- and Lava Ridge-Hell's Half Acre volcanic rift zones generally have fewer and older volcanic vents; therefore, eruption probabilities decrease northwestward from the axial volcanic zone. Specific sites of future eruptions cannot be forecast, however, an estimate of the probability of future lava flow inundation within the axial volcanic zone is possible. The axial volcanic zone generally coincides with the southern portion of lava flow Hazard Zone 1 . It is assumed that every eruption will produce a lava flow of average dimensions, and terrain factors are ignored. The average INEL lava flow of the past 400,000 years is $8 \mathrm{~km}$ long and covers 47 square $\mathrm{km}$. Near the INEL, the area of the axial volcanic zone is about 1,000 square $\mathrm{km}$. The annual probability of a $47 \mathrm{~km}^{2}$ lava flow inundating a random site within the axial volcanic zone is therefore

[P1, annual probability of lava eruption within the source zone] $\mathrm{x}$

$[\mathrm{P} 2$, probability of inundation, (area of lava / area of entire source zone) $]=$

$\left(6.2 \times 10^{-5} \mathrm{yr}^{-1}\right) \times\left(47 \mathrm{~km}^{2} / 1,000 \mathrm{~km}^{2}\right)=2.9 \times 10^{-6} \mathrm{yr}^{-1}$

The Arco volcanic rift zone has erupted about as frequently as the axial volcanic zone, and it covers about 300 square $\mathrm{km}$. The annual probability of a typical INEL lava flow inundating a random site within the Arco volcanic rift zone is, therefore, approximately $9.3 \times 10^{-6}$ per year. For a random site within the Lava Ridge - Hell's Half Acre volcanic rift zone (40,000-year recurrence within a 500 square-km area), the probability of lava inundation is about $2.4 \times 10^{-6}$ per year.

It is important to emphasize that these general lava-inundation probabilities are not equivalent to site-specific risk assessments, because only source terms were considered within the context of several simplifying assumptions. Site-specific assessments must incorporate other factors including distance from the source zone(s) (whereas, in the above exercise, a random location within a source zone was assumed), the influence of local terrain upon lava flow paths, the 
consequences of volcanic effects, and the potential success of mitigation measures (e.g., construction of barriers or removal of property). The general inundation probabilities given above may be considered analogous to the estimated probability of an earthquake with a certain magnitude occurring within a certain fault zone, in the context of seismic-hazard assessment. Ground-motion estimates at specific facilities, conceptually analogous to volcanic-risk assessments at specific facilities, require additional knowledge of distance from source (lava flow lengths), the effects of subsurface materials upon the energy of seismic waves (probable paths of lava flows), and the sitespecific geologic conditions (the site is topographically favorable or unfavorable to lava flow inundation).

For the other hazardous phenomena discussed below, annual probabilities of occurrence will correspond to the recurrence data of Table 3 . This is because tephra fall, volcanic-gas emission, and magma-induced ground deformation are expected to accompany virtually all basaltic volcanic eruptions. However, the affected areas are assessed to be smaller than the areas inundated by lava flows.

\subsection{Tephra Fall and Volcanic Gases}

For Hawaiian (lava flow) and strombolian (cinder cone) basaltic eruptions, the effects of tephra fall and toxic or corrosive gases will be generally restricted to within about $1 \mathrm{~km}$ of vents, but the strong southwest winds of the ESRP may carry these materials several kilometers downwind. Tephra and gas-hazard zones (Figure 9) are therefore indicated for areas $0.5 \mathrm{~km}$ southwest and $2 \mathrm{~km}$ northeast of $\mathrm{Qb} \mathrm{a}, \mathrm{b}$ and $\mathrm{c}$ vents and fissures within the INEL volcanic zones. Corresponding zones for tephra and gases from silicic-dome eruptions along the axial volcanic zone are estimated to be about twice these dimensions (5-km radius) and would also include pyroclastic-flow hazards. A separate zone for silicic tephra and gases is not drawn along the axial volcanic zone, but is understood to exist within the basaltic-tephra hazard zone for that area. A northern lobe of volcanic-gas hazard zonation is indicated in the north-central INEL, near Test Area North. This is a topographic depression that could trap dense volcanic gases during temperature inversions or static-air conditions. Tephra fall and gas emission are expected to accompany all volcanic eruptions, and gas emission from fissures would accompany dike intrusion even in the absence of lava eruption onto the surface. The recurrence of gas and tephra phenomena is therefore considered to be equal to or greater than lava flow recurrence within the INEL volcanic zones, but the areas affected by gas and tephra are substantially smaller than for lava flows.

\subsection{Ground Deformation Associated with Dike Intrusion}

The widespread occurrence of fissure-erupted lava flows and the extensional deformation features of ESRP volcanic rift zones indicate that basaltic eruptions on the ESRP are fed by dikes. Areas within $1 \mathrm{~km}$ of $\mathrm{Qb} \mathrm{a}, \mathrm{b}$, or $\mathrm{c}$ vents and all areas with magma-induced fissures and faults comprise the zone of ground-deformation hazard (Figure 10). The Arco volcanic rift zone includes many such deformation features associated with fissure-fed lava flows and small pyroclastic cones, indicating that repeated dike intrusions occurred in the area. Although generally lacking grounddeformation features, much of the axial volcanic zone is also included as part of the grounddeformation hazard zone, because it is reasonably inferred that fissures formed, but were covered by cogenetic lava flows from the many vents of the area. It appears that the ratio of extrusive to intrusive events is greater in the axial volcanic zone than in the Arco volcanic rift zone (i.e., either 
the axial volcanic zone has been resurfaced more frequently, or there have been more "dry" dike intrusions beneath the northern Arco rift zone than elsewhere). As previously discussed under lava flow hazard zones, several isolated fissures near the Naval Reactors Facility in the western-central portion of INEL are not considered to be a potential zone of future magma intrusion or eruption.

Ground deformation is expected to accompany all shallow dike-intrusion events, with or without volcanic eruption. The recurrence of ground-deformation phenomena is, therefore, considered equal to or greater than lava flow recurrence within the INEL volcanic zones (Table 3). The severity of vertical offset and ground fissuring will vary according to the number of dikes and their aggregate thickness. The affected areas are assessed to be restricted to the volcanic zones and to be substantially smaller than areas of lava inundation.

\subsection{Comparison of INEL and Hawaiian Hazard Zones}

This report closely follows the approach of Mullineaux et al. (1987) for mapping volcanic hazards in the Hawaiian Islands, an intensively studied region of active basaltic volcanism. The tectonic settings and regional-volcanic configurations differ substantially for Hawaii and the ESRP, but many of the basaltic-eruption phenomena are similar, allowing a similar approach to volcanichazard assessment. Although their phenomena are similar, the levels of hazard for the INEL are much lower than for the Hawaiian Islands, mainly because INEL volcanic recurrence is much longer. The active Hawaiian rift zones erupt every few decades or centuries, with annual probabilities of the order $10^{-1}$ to $10^{-2}$ per year. In contrast, INEL volcanic rift zones have erupted with frequencies of every 16,000 to 100,000 years $\left(6.2 \times 10^{-5}\right.$ to $1.0 \times 10^{-5}$ per year $)$ and the most recent volcanism that affected the INEL occurred more than 5,000 years ago. Zones of "high" hazard for the INEL, therefore, correspond to zones of very low hazard in Hawaii. Thus, INEL lava flow zones 1 and 2 are roughly analogous to zones 8 and 9 on the island of Hawaii, or to zones 4 and 5 on the island of Maui, areas which have not been inundated by lava for 10,000 years or more, and for which the average lava flow recurrence is estimated to be longer than 10,000 years. The volcanic hazards in such areas of Hawaii would be considered insignificant, and barring other factors, these zones would be considered safe for residential or commercial development.

\section{CONCLUSIONS}

Volcanic hazards have been evaluated for the INEL because critical facilities and long-term waste-storage sites have more stringent performance requirements than residential dwellings, and the regulations governing such facilities demand that all potentially hazardous, natural phenomena be examined in the interests of safety. The scope and format of this report have been designed to accommodate INEL geologic information that is likely to become available in the near future. In particular, new geochronologic data might lead to revision of the recurrence estimates. Recurrence estimates for the INEL volcanic zones in turn are the basis of probabilistic volcanic-risk assessments for existing or planned INEL facilities. 


\section{REFERENCES}

Anderson, S. R., and B. D. Lewis, 1989, Stratigraphy of the Unsaturated Zone at the Radioactive Waste Management Complex, Idaho National Engineering Laboratory, Idaho, U.S.

Geological Survey Water-Resources Investigations Report 89-4065, 54 p.

Barberi, F., M. L. Carapezza, M. Valenza, and L. Villari, 1993, "The Control of Lava Flow during the 1991-1992 Eruption of Etna," Journal of Volcanology and Geothermal Research, v. 56, p. 1-34.

Blong, R. J., 1984, Volcanic Hazards - A Sourcebook on the Effects of Eruptions, Academic Press, Orlando, Florida, 424 pp.

Champion, D. E.; M. A. Lanphere, and M. A. Kuntz, 1988, "Evidence for a New Geomagnetic Reversal from Lava Flows in Idaho: Discussion of Short Polarity Reversals in the Brunhes and Late Matuyama Polarity Chrons," Journal of Geophysical Research, v. 93, p. 11,66711,680 .

Decker, R. W., T. L. Wright, and P. H. Stauffer, editors, 1987, Volcanism in Hawaii, U.S. Geological Survey Professional Paper 1350, 1667 pp.

Fink, J. H., editor, 1990, "Lava Flows and Domes - Emplacement Mechanisms and Hazard Implications," IAVCEI Proceedings in Volcanology 2, Springer-Verlag, New York, 249 pp.

Fishel, M., 1993, Geology and Petrology of Uplifted Mafic Lavas on the North Flank of Big Southern Butte, Eastern Snake River Plain, Idaho, Masters thesis, Idaho State University, Pocatello, Idaho.

Fournier d'Albe, E. M., 1986, Reducing Vulnerability to Nature's Violent Forces: Cooperation Between Scientist and Citizen, in Robert H. Maybury, editor, Violent Forces of Nature, Lomond Publications, Mt. Airy, Maryland, p. 1-6.

Golder Associates, 1992, New Production Reactor Site Characterization, Volume 1, Volcanic Zones Geologic Mapping Report, EG\&G Idaho, Inc., Informal Report EGG-NPR-10625, February 1992.

Greeley, R., 1982, The Style of Basaltic Volcanism in the Eastern Snake River Plain, Idaho, in Bill Bonnichsen and R. M. Breckenridge, editors, Cenozoic Geology of Idaho, Idaho Bureau of Mines and Geology Bulletin 26, p. 407-422.

Gudmundsson, A., 1987, "Tectonics of the Thingvellir Fissure Swarm, Southwest Iceland," Journal of Structural Geology, v. 9, p. 61-69.

Hackett, W. R., and L. A. Morgan, 1988, Explosive Basaltic and Rhyolitic Volcanism of the Eastern Snake River Plain, Idaho, in Link, P. K., and Hackett, W. R., editors, Guidebook to the Geology of Central and Southern Idaho, Idaho Geological Survey Bulletin 27, p. 283301. 
Hackett, W. R., and R. P. Smith, 1992, Quaternary Volcanism, Tectonics and Sedimentation in the Idaho National Engineering Laboratory area, in James R. Wilson, editor, Field Guide to Geologic Excursions in Utah and Adjacent areas of Nevada, Idaho and Wyoming, Utah Geological Survey Miscellaneous Publication 92-3, p. 1-18.

Hayden, K., 1992, Geology and Petrology of the Cedar Butte Eruptive Center, Eastern Snake River Plain, Idaho, Masters thesis, Idaho State University, Pocatello, Idaho.

Hildreth, W., A. N. Halliday, and R. L. Christiansen, 1991, "Isotopic and Chemical Evidence Concerning the Genesis and Contamination of Basaltic and Rhyolitic Magma Beneath the Yellowstone Plateau Volcanic Field," Journal of Petrology, v. 32, p. 63-138.

Imsland, P., 1989, "Study Models for Volcanic Hazards in Iceland," in J. H. Latter, editor, Volcanic Hazards - Assessment and Monitoring, IAVCEI Proceedings in Volcanology 1, Springer-Verlag, New York, p. 36-56.

Jackson, S. M., 1994, Maximum Magnitudes of Earthquakes Associated with Basalt Dike Intrusion for Use in INEL Seismic Hazards Assessments, INEL-94/0132, 42 p.

Kilburn, C. J., and G. Luongo, editors, 1994, Active Lavas: Monitoring and Modeling, University College London Press, London, 374 pp.

Kuntz, M. A., 1978, Geology of the Arco-Big Southern Butte Area, Eastern Snake River Plain, and Potential Volcanic Hazards to the Radioactive Waste Management Complex and Other Waste Storage and Reactor Facilities at the Idaho National Engineering Laboratory, Idaho, U. S. Geological Survey Open-File Report 78-691, 70 pp.

Kuntz, M. A., 1992, A Model-Based Perspective of Basaltic Volcanism, Eastern Snake River Plain, Idaho, in Link, P.K., M. A. Kuntz, and L. B. Platt, editors, Regional Geology of Eastern Idaho and Western Wyoming, Geological Society of America Memoir 179, p. 289304.

Kuntz, M. A. and G. B. Dalrymple, 1979, Geology, Geochronology and Potential Volcanic Hazards in the Lava Ridge-Hell's Half Acre Area, Eastern Snake River Plain, Idaho, U. S. Geological Survey Open-File Report 79-1657, 65 p.

Kuntz, M. A., E. C. Spiker, M. Rubin, D. E. Champion, and R. H. Lefebvre, 1986, "Radiocarbon Studies of Latest Pleistocers and Holocene Lava Flows of the Snake River Plain, Idaho: data, lessons, interpretations," Quaternary Research, v. 25, p. 163-176.

Kuntz, M. A., D. E. Champion, R. H. Lefebvre, and H. R. Covington, 1988, Geologic Map of the Craters of the Moon, Kings Bowl, and Wapi Lava Fields, and the Great Rift Volcanic Rift Zone, South-Central Idaho, U. S. Geological Survey Miscellaneous Investigations Series Map I-1632, 1:100,000 scale. 
Kuntz, M. A., H. R. Covington, and L. J. Schorr, 1992, An Overview of Basaltic Volcanism of the Eastern Snake River Plain, Idaho, in Link, P.K., M. A. Kuntz, and L. B. Platt, editors, Regional Geology of Eastern Idaho and Western Wyoming, Geological Society of America Memoir 179, p. 227-268.

Kuntz, M. A., B. Skipp, M. A. Lanphere, W. E. Scott, K. L. Pierce, G. B. Dalrymple, D. E. Champion, G. F. Embree, W. R. Page, L. A. Morgan, R. P. Smith, W. R. Hackett, and D. W. Rodgers, 1994, Geoligic Map of the Idaho National Engineering Laboratory and Adjoining Areas, Eastern Idaho, U.S. Geological Survey Miscellaneous Investigations Map I-2330, 1:100,000 scale.

Latter, J. H., 1989, editor, "Volcanic Hazards - Assessment and Monitoring," IAVCEI Proceedings in Volcanology 1, Springer-Verlag, New York, 625 pp.

Morgan, L. A., D. J. Doherty, and W. P. Leeman, 1984, "Ignimbrites of the Eastern Snake River Plain: Evidence for Major Caldera-Forming Eruptions," Journal of Geophysical Research, v. 89 , p. $8665-8678$.

Mullineaux, D. R., D. W. Peterson, and D. R. Crandell, 1987, Volcanic Hazards in the Hawaiian Islands, in Decker, R.W., T. L. Wright, and P. H. Stauffer, editors, Volcanism in Hawaii, U.S. Geological Survey Professional Paper 1350, p. 599-621.

Pierce, K. L., and L. A. Morgan, 1992, The Track of the Yellowstone Hotspot - Volcanism, Faulting and Uplift, in Link, P.K., M. A. Kuntz, and L. B. Platt, editors, Regional Geology of Eastern Idaho and Western Wyoming, Geological Society of America Memoir 179, p. 154.

Reiter, L., 1990, Earthquake Hazard Analysis, Issues and Insights, Columbia University Press, New York, 254 pp.

Scott, W. E., 1982, Surficial Geologic Map of the Eastern Snake River Plain and Adjacent Areas, 111 to 115 degrees W., Idaho and Wyoming, U.S. Geological Survey Miscellaneous Investigations Series Map I-1372, 2 sheets, 1:250,000.

Sigurdsson, H., 1980, "Surface Deformation of the Krafla Fissure Swarm in Two Rifting Events," Journal of Geophysics, v. 47, p. 154-159.

Smith, R. B., and Braile, L. W., 1993, Topographic Signature, Space-Time Evolution, and Physical Properties of the "owstone-Snake River Plain Volcanic System: the Yellowstone Hotspot, in Snake, A. W., J. R. Steidtmann, S. M. Roberts, editors, Geology of Wyoming, Geological Survey of Wyoming Memoir No. 5, p. 694-754.

Smith, R. B., and R. L. Christiansen, 1980, "Yellowstone Park as a Window on the Earth's Interior," Scientific American, February 1980.

Smith, R. P., 1994, Potential Impacts of Selected Magmatic Processes at Test Area North, EG\&G Idaho, Inc., Engineering Design File EDF-TANO-94-23, 7 pp. 
Smith, R. P., W. R. Hackett, and D. W. Rodgers, 1989, "Geologic Aspects of Seismic-Hazards Assessment at the Idaho National Engineering Laboratory, Southeastern Idaho," Proceedings: Second DOE Natural Phenomena Hazards Mitigation Conference, p. 282-289.

Smith, R. P., S. M. Jackson, and W. R. Hackett, 1995 in press, "Paleoseismology in Extensional Volcanic Terrains," Journal of Geophysical Research.

Spear, D. B. and J. S. King, 1982, The Geology of Big Southern Butte, Idaho, in Bonnichsen, Bill, and Breckenridge, R. M., editors, Cenozoic Geology of Idaho, Idaho Bureau of Mines and Geology Bulletin 26, p. 395-403.

Tilling, R. I, and D. W. Peterson, 1994, Field Observation of Active Lava in Hawaii: Some Practical Considerations, in Kilburn, C.J. and G. Luongo, editors, Active Lavas: Monitoring and Modeling: University College London Press, London, p. 147-174.

Volcanism Working Group, 1990, Assessment of Potential Volcanic Hazards for New Production Reactor Site at the INEL, EG\&G Informal Report, EGG-NPR-10624, 98 pp.

Womer, M. B., R. Greeley, and J. S. King, Phreatic Eruptions of the Eastern Snake River Plain of Idaho, in Bonnichsen, Bill, and Breckenridge, R. M., editors, Cenozoic Geology of Idaho, Idaho Bureau of Mines and Geology Bulletin 26, p. 453-464.

Wright, T. L., J. Y. Chun, J. Esposo, C. Heliker, J. Hodge, J. P. Lockwood, and S. M. Vogt, 1992, Map Showing Lava Flow Hazard Zones, Island of Hawaii, U.S. Geological Survey Miscellaneous Field Studies Map MF-2193, 1:250,000. 


\section{M98052557}

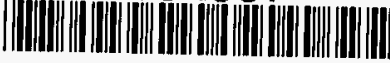

Report Number (14)_INEL=94/0276

Jubl. Date (11)

Sponsor Code (18)

JC Category (19) UC-2000, DOE/ER 